\title{
Soil Carbon
}

\author{
Erin Berryman, Jeffrey Hatten, Deborah S. Page- \\ Dumroese, Katherine A. Heckman, David V. D'Amore, \\ Jennifer Puttere, Michael SanClements, \\ Stephanie J. Connolly, Charles H. (Hobie) Perry, \\ and Grant M. Domke
}

\section{Introduction}

Soil organic matter $(\mathrm{OM})$ is a pervasive material composed of carbon $(\mathrm{C})$ and other elements. It includes the $\mathrm{O}$ horizon (e.g., litter and duff), senesced plant materials within the mineral soil matrix, dead organisms (including macroorganisms and microorganisms), microbial and root exudates, and organic materials adhering to mineral surfaces. Soil organic carbon (SOC) is a very dynamic component of the soil; each year, the amount of SOC processed by microorganisms within the soil is roughly equal to the amount of inputs from plant detritus. The pervasive dynamic nature of SOC is key to the ecosystem services, or "the benefits people obtain from ecosystems" (Millennium Ecosystem Assessment 2003), that SOC provides.

\section{Sidebar 2.1 Tool and research needs pertaining to soil organic carbon}

- A mechanism to transfer knowledge about the new SOC paradigm to forest and rangeland managers and use that knowledge to develop best management practices for building up SOC

E. Berryman $(\bowtie)$

Forest Health Protection, State and Private Forestry, USDA Forest Service, Fort Collins, CO, USA

U.S. Department of Agriculture, Forest Service, Forest Health Assessment and Applied Sciences Team, Fort Collins, CO, USA e-mail: Erin.berryman@usda.gov

J. Hatten

Oregon State University, College of Forestry, Forest Engineering, Resources \& Management, Corvallis, OR, USA

D. S. Page-Dumroese

Rocky Mountain Research Station, USDA Forest Service,

Moscow, ID, USA

\section{K. A. Heckman}

U.S. Department of Agriculture, Forest Service, Northern Research Station, Houghton, MI, USA
- Quantitative models of SOC stabilization and vulnerability designed for management applications (e.g., Forest Vegetation Simulator with SOC module)

- Improved linkage of Ecological Site Descriptions to management actions that impact SOC

- Synchronization of SOC data across multiple agencies and sampling initiatives

- Models that link forest health and drought resistance to changes in SOC

Soil organic carbon is an essential indicator of soil health. Soil health refers to the "ability of soil to function effectively as a component of a healthy ecosystem" (Schoenholtz et al. 2000 , p. 335). The quantity and quality of SOC are linked to important soil functions including nutrient mineralization, aggregate stability, trafficability, permeability to air, water retention, infiltration, and flood control (Box 2.1). In turn, these soil functions are correlated with a wide range of ecosystem properties. For example, high SOC in mineral soils is usually associated with high plant productivity (Oldfield et al. 2017), with subsequent positive implications for wild-

\section{V. D'Amore}

U.S. Department of Agriculture, Forest Service, Pacific Northwest Research Station, Juneau, AK, USA

J. Puttere

U.S. Department of Interior, Bureau of Land Management, Springfield, OR, USA

\section{SanClements}

National Ecological Observatory Network, Boulder, CO, USA

S. J. Connolly

U.S. Department of Agriculture, Forest Service, Northern Research Station, Newtown Square, PA, USA

C. H. (Hobie) Perry · G. M. Domke

U.S. Department of Agriculture, Forest Service, Northern Research Station, St. Paul, MN, USA 


\section{Box 2.1 Benefits of Soil Organic Matter and Soil Carbon}

Soil carbon (C), a major component of soil organic matter (SOM), provides several benefits for the function of forests, rangelands, and other wildlands. In addition, soil $\mathrm{C}$ is correlated to many other properties that enhance ecosystem services and is thus a strong indicator of soil health. Many of these ecosystem services are interdependent: Promoting soil $\mathrm{C}$ buildup starts a chain reaction that ultimately improves many facets of ecosystem health. Among the benefits of soil $\mathrm{C}$ and soil organic matter are that they:

Boost nutrient storage-soils with high soil $\mathrm{C}$ tend to have high nutrient content, promoting growth of trees and forage. About $99 \%$ of soil nitrogen $(\mathrm{N})$ is found within SOM. In addition, SOM provides much of the cation exchange capacity essential for making nutrients available to plant roots.

Enhance soil structure-SOM holds soil particles together through adhesion and entanglement, reducing erosion and allowing root movement and access to nutrients and water.

Act as a large biological carbon store-through stabilization mechanisms (see text), the formation of soil $\mathrm{C}$ feeds a major reservoir of global $\mathrm{C}$. With the right management, increases in soil $\mathrm{C}$ storage can be large enough to offset a portion of anthropogenic greenhouse gas emissions.

Enhance plant carbon sequestration-by increasing nutrient and water availability, soils with high soil C and organic matter support increased growth of forests, rangelands, and wildlands, leading to increased uptake of atmospheric $\mathrm{CO}_{2}$.

Increase ecosystem water storage-through enhancing soil structure and increasing soils' effective surface area, SOM increases the amount of water that can be retained in the soil for plant and downstream use, reducing evaporative and runoff losses.

Purify drinking water-the effects of SOM on water holding capacity and soil structure help to enhance soil's resilience to erosion. Soil organic matter also plays a role in reducing the bioavailability of pollutants. These functions contribute to SOM's strong role in purifying water for human uses.

Detoxify soil-by affecting nutrient availability and soil structure, and by serving as an energy source for microbes, SOM plays an important role in maintaining soil health. By reducing the content, bioavailability, and mobility of compounds, SOM supports soil's ability to detoxify pollutants that occur as a result of chemical spills or contamination. life habitat, distribution, and abundance. Consequently, ecosystem services can be degraded when SOC is altered or lost from forest or rangeland sites. Measuring and monitoring SOC levels can lead to a more complete understanding of ecosystem and soil health at a particular site; indices of soil health incorporate measures of SOC and can be used to track changes in soil health over time and in response to management activities (Amacher et al. 2007; Chaer et al. 2009).

Soils account for the largest pool of terrestrial organic C globally, with an estimated $2.27-2.77 \times 10^{15} \mathrm{~kg}$ or $2270-2770$ petagrams $(\mathrm{Pg})$ of $\mathrm{C}$ in the top 2-3 $\mathrm{m}$ of soil (Jackson et al. 2017). This represents a pool that is two to three times larger than the atmospheric and biotic $\mathrm{C}$ pools. North American and US soils (all soil orders) store about $366 \mathrm{Pg} \mathrm{C}$ and 73.4 Pg C, respectively, in the top $1 \mathrm{~m}$ (Liu et al. 2013; Sundquist et al. 2009; USGCRP 2018). Most of the SOC stock in the United States is in nonintensively managed lands such as forests (Fig. 2.1), wetlands, and rangelands (Liu et al. 2012, 2014). Across land uses, most SOC is concentrated near the surface, where it may be vulnerable to loss; $74.5 \%$ of North America's SOC occurs in the top $30 \mathrm{~cm}$ of mineral soil (Batjes 2016; Scharlemann et al. 2014). Most assessments of SOC pools represent only mineral SOC and have omitted organic soil horizons that sit on top of the mineral soil, despite the importance of $\mathrm{O}$ horizons as a source of OM for building SOC. In this chapter we will refer to "O horizons" and "forest floors" when talking about organic soil horizons on top of the mineral soil, "mineral soil" when discussing mineral-dominated soil horizons, SOC as mineral soil organic C, and "soil" as everything from the $\mathrm{O}$ horizon and deeper. If included in the above estimates, $\mathrm{O}$ horizons would increase the global SOC pool estimates by about $43 \mathrm{Pg}$ (Pan et al. 2011) or about $2 \%$ of the total SOC pool. However, O horizons are more important in forests than in rangelands. Domke and others (2016, 2017) found that forest floor O horizons accounted for about $12 \%$ of the SOC pool; forest SOC had a density of about $63 \mathrm{Mg} \mathrm{ha}^{-1}$ and litter represented roughly $8 \mathrm{Mg} \mathrm{ha}^{-1}$ across all USDA Forest Service (hereafter, Forest Service) Forest Inventory and Analysis (FIA) plots (Fig. 2.2; Box 2.2).

Accurate assessment and ongoing monitoring of national SOC stocks are a critical first step to understanding how management activities can impact this national resource. Because the SOC pool is large compared to other $\mathrm{C}$ pools (especially the atmosphere), a small change in SOC can produce a large change in atmospheric carbon dioxide $\left(\mathrm{CO}_{2}\right)$ levels. For example, a global decrease in SOC of 5\% in the upper $3 \mathrm{~m}$ would result in $117 \mathrm{Pg}$ of $\mathrm{C}$ released into the atmosphere, causing an increase in the atmospheric $\mathrm{C}$ pool (829 $\mathrm{Pg}$ in 2013) of 14\%, i.e., from $400 \mathrm{ppm}$ to $456 \mathrm{ppm} \mathrm{CO}_{2}$. Conversely, sequestering a small percentage in this large $\mathrm{C}$ pool translates into a substantial increase that is globally relevant. Site-level studies suggest that reforestation and other land-use and management changes increase SOC by $0.1-$ $0.4 \mathrm{Mg} \mathrm{C} \mathrm{ha}{ }^{-1}$ year $^{-1}$, and a national-scale (conterminous 

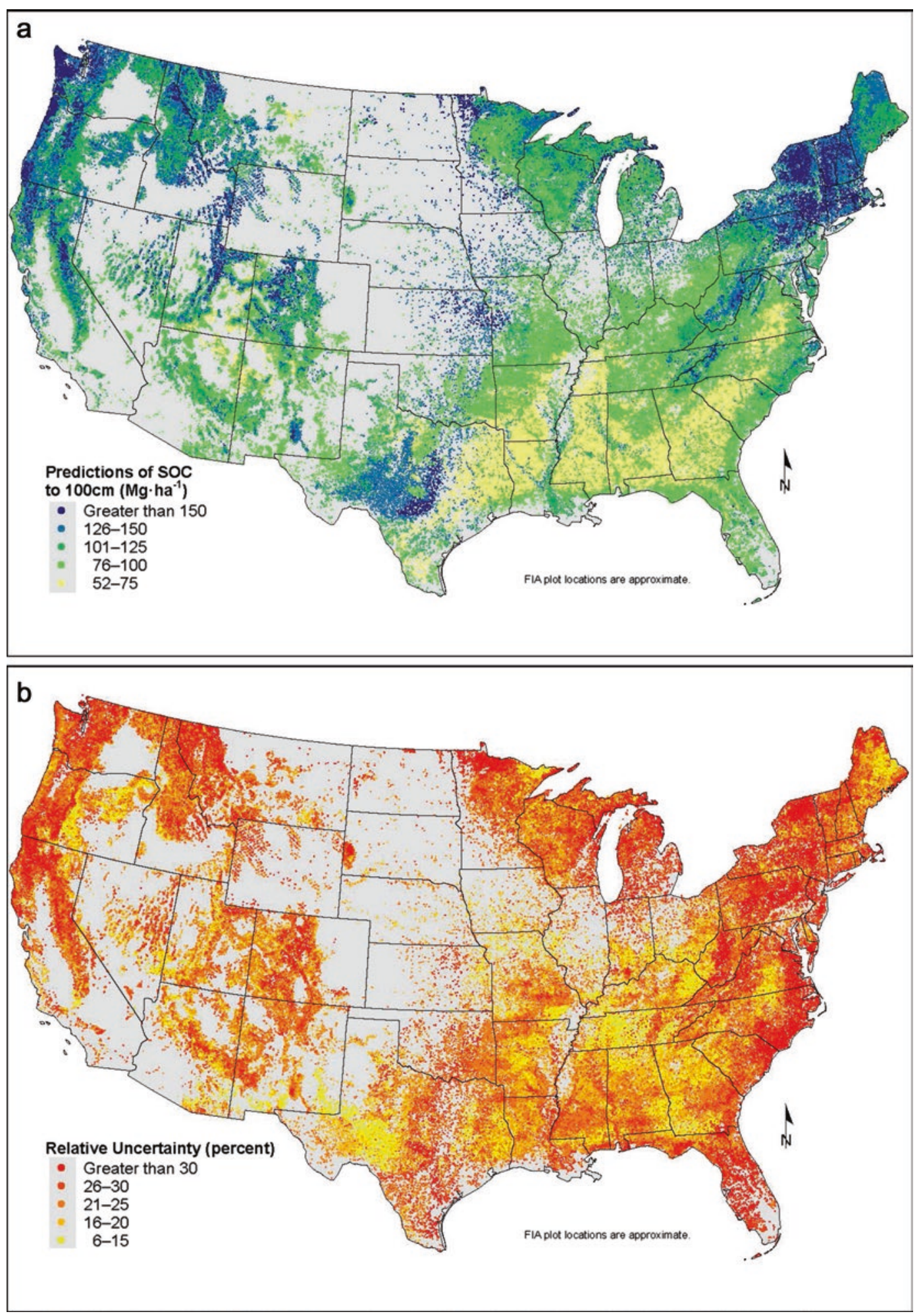

Fig. 2.1 (a) Map of soil C stores predicted at Forest Service Forest Inventory and Analysis plots. (b) Map of uncertainty in predictions of soil C stores at these plots. (Source: Domke et al. 2017)

United States) analysis suggests that reforesting topsoils are accumulating $13-21 \times 10^{9} \mathrm{~kg}$ or $13-21$ teragrams $(\mathrm{Tg}) \mathrm{C}$ year. ${ }^{-1}$ with the potential to sequester hundreds more teragrams C within a century (Nave et al. 2018).
In the past few decades, there have been several coordinated efforts to assess national-level SOC stocks in a statistically robust manner (Box 2.2). Such assessments provide a baseline for detecting future change in United States 

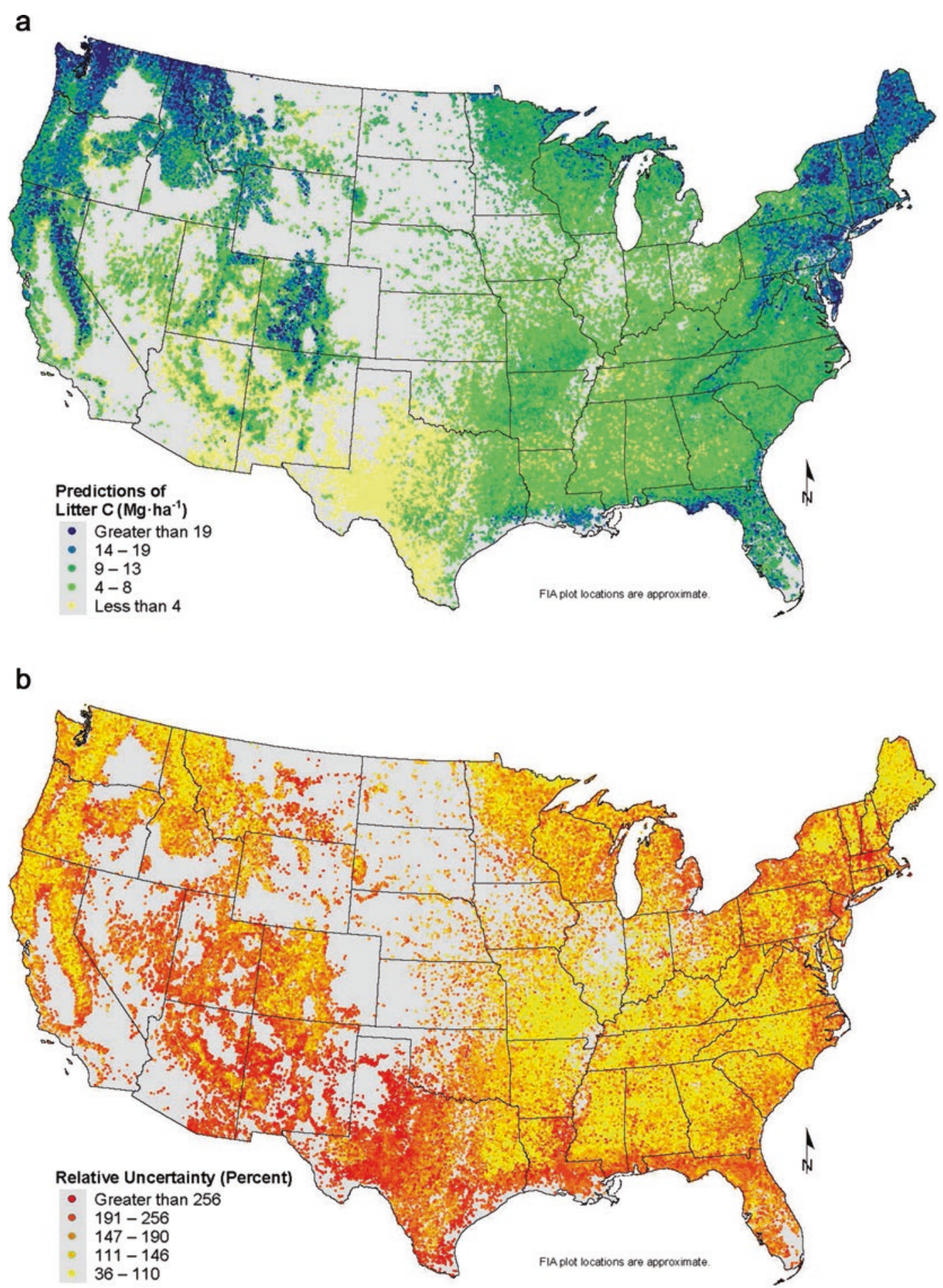

Fig. 2.2 (a) Map of litter (forest floor) C stores predicted at Forest Service Forest Inventory and Analysis plots. (b) Map of uncertainty in predictions of litter C stores at these plots. (Source: Domke et al. 2016)

SOC. Yet there are some limitations to national-scale assessments. One is varying depth of soil and, consequently, SOC stocks across the country. Most assessments do not consider soil deeper than $1 \mathrm{~m}$, even though deeper soil can be an important reservoir of SOC (Harrison et al. 2011).
Furthermore, in any study of SOC on a specific site, it is difficult to detect SOC changes less than about 25\% (e.g., Homann et al. 2001) due to soil heterogeneity (Fig. 2.1b) and sampling and measurement error. Though controlled experiments (e.g., laboratory incubations) demonstrate that some 


\section{Box 2.2 Assessing the Nation's Soil Organic Carbon} Stores

There have been many efforts to characterize soil organic carbon (SOC) at a national scale. A major challenge to accurate accounting of SOC is the high spatial variability of SOC content, which results in large uncertainties and may preclude the detection of change over time. Each effort has slightly different goals and objectives, but they all emphasize free and open data availability.

The USDA Forest Service's Forest Inventory and Analysis (FIA) program (https://www.fia.fs.fed.us/ library/brochures/docs/Forest_Health_Indicators.pdf) reports on the status and trends of the nation's forest resource, across all ownerships. The field campaign of FIA collects information on the area of forest land and its location; the species, size, and health of trees; and total tree growth, mortality, and removals by harvest and land-use change. In 2000, the Forest Service greatly enhanced the FIA program in several ways. It changed from a periodic survey to an annual survey (the field crew returns to each plot every 5 or 10 years), and it expanded the scope of data collection to include soil, understory vegetation, tree crown conditions, coarse woody debris, and lichen community composition on a subsample of plots. It also increased our capacity to analyze and publish the underlying data as well as information and knowledge products derived from it. To facilitate forest SOC estimation, FIA collects data on litter thickness and mass, $\mathrm{C}$ content, mineral soil bulk density, and rock fraction at repeatable depth intervals $(0-10 \mathrm{~cm}, 10-20 \mathrm{~cm})\left(\mathrm{O}^{\prime} \mathrm{Neill}\right.$ et al. 2005). These measurements can be used in combination with other site attributes and ancillary information to generate robust, statistically sound estimates of forest floor and litter C (Domke et al. 2016) and SOC (Domke et al. 2017) at a national scale. An advantage of FIA over other assessment efforts is the repeated nature of the survey; eventually, change in soil properties over time may be possible to detect. However, the spatial density of the subsample of FIA plots where soil data are collected is very low (1 plot per 103,000 ha), so subnational assessments should consider additional soil data such as those collected by the national forests or Natural Resources Conservation Service (NRCS).

Rapid Carbon Assessment (RaCA; https://www. nrcs.usda.gov/wps/portal/nrcs/detail/soils/survey/?cid $\left.=n r c s 142 p 2 \_054164\right)$ was initiated in 2010 as an organized, coordinated effort led by NRCS to systematically sample and measure SOC across the United
States using a consistent and repeatable methodology. Data are intended to represent a snapshot in time of the national inventory of SOC under various land covers and differing agricultural management. This assessment sampled 6017 plots across the country and emphasized statistically reliable and defensible methods. Forthcoming analyses from RaCA data will represent a comprehensive accounting of SOC stocks under major land-use categories across the United States, regardless of ecosystem type or land ownership status.

National Cooperative Soil Survey (NCSS; https:// www.nrcs.usda.gov/wps/portal/nrcs/main/soils/survey/partnership/ncss) is a nationwide partnership of Federal, regional, state, and local agencies and private entities and institutions that was created to document soil taxonomy using consistent methods. Participants cooperate with each other to gather information about soils using common or shared procedures. Natural Resources Conservation Service runs soil surveys at the county level. The Forest Service conducts soil surveys in many of its national forests, as does the Department of the Interior's National Park Service in some national parks. An important product of the NCSS is the Gridded Soil Survey Geographic (gSSURGO) database, a spatial data layer (10 m resolution) of various soil properties derived from soil series that are mapped, delineated as "map units." Each map unit is linked to specific soil properties in a comprehensive database, which includes SOC. However, gSSURGO is not intended to be a statistically robust map of SOC. The spatial accuracy of specific soil attributes is not defined and may vary widely across the United States. In addition, gaps exist in gSSURGO in areas where soil survey data are not available, such as regions or counties that have not been mapped yet.

The International Soil Carbon Network (ISCN; https://iscn.fluxdata.org) is an ad hoc research coordination network that "facilitates data sharing, assembles databases, identifies gaps in data coverage, and enables spatially explicit assessments of soil $\mathrm{C}$ in context of landscape, climate, land use, and biotic variables" (ISCN n.d.). Data are derived from independent research projects, so they represent a wide range of geographic coverage, temporal resolutions, and methods.

perturbation will cause change (e.g., soil warming), it can be difficult to detect this change in the field. The inclusion of rocks larger than $2 \mathrm{~mm}$ in samples, changes in texture, and sensitivity of SOC stocks to bulk density all contribute to error in assessing SOC (Jurgensen et al. 2017; Page- 
Dumroese et al. 1999). Improved measurement technology and statistical methods that account for different sources of uncertainty may help overcome these challenges and allow for the detection of more subtle changes in SOC.

While essential for national soil $\mathrm{C}$ accounting purposes, nationwide assessments like FIA may not be helpful for regional or local management challenges due to their coarse spatial resolution. In 1976, the National Forest Management Act was enacted and set forth three points that would necessitate soil monitoring and analysis on national forests to inform planning. The first point was that land management could not produce substantial or permanent impairment of site productivity. Second, trees could be harvested only where soil, slope, or watershed conditions would not be irreversibly damaged. Last, harvesting had to protect soil, watershed, fish, wildlife, recreational, and aesthetic resources. In support of national forest managers' decision-making, soil monitoring standards and guidelines were developed nationwide to determine baseline soil properties and identify changes associated with harvesting (Neary et al. 2010). In addition, many national forests have developed and maintained soil monitoring protocols unique to their needs. For example, the Monongahela National Forest in West Virginia has a long-running soil monitoring program ( $>20$ years) that originated from the need to understand acid deposition impacts on soil and water health. It is important to recognize that National Forest System data may not include SOC nor is it incorporated into national-scale assessments. Many national forests lack funding and personnel to sample and analyze harvest-unit soil and vegetation changes, hindering the ability of local managers to consider SOC benefits and impacts when developing management plans. Remote sensing using light detection and ranging (LiDAR) or highresolution satellite images can help quantify aboveground forest C (e.g., Gonzalez et al. 2010), and, where available, SOC can be predicted by using near infrared reflectance hyperspectral proximal data combined with remote sensing data (Gomez et al. 2008). In most cases, however, efforts to quantify changes in SOC must rely on archived soil samples combined with new sampling and analysis to determine changes in surface and subsurface pool sizes.

\section{Mechanisms of Mineral Soil Organic Carbon Stability and Vulnerability: An Emerging Paradigm}

For a long time, our understanding of SOC distribution and vulnerability was limited by the traditional SOC conceptual model in use for many decades. Arising from advances in technology that allow fine-scale molecular and microbial investigations of SOC interactions with mineral soil, a new conceptual framework of SOC stabilization and destabiliza- tion is being developed that improves our ability to predict SOC behavior. Important advances have been made in our knowledge of the source and stabilization mechanisms of mineral-associated SOC.

Organic matter quality is used as a general descriptor for the combination of the chemical structure and elemental composition of $\mathrm{OM}$ that influences decomposition. Historically it was thought that the ability of an organism to effectively decompose OM was directly related to the material's molecular composition (such as lignin content) and concentration of nutrients (such as nitrogen $(\mathrm{N})$ ). These concepts are still useful when describing decomposition dynamics of organic soils or organic soil horizons, but measures of OM quality have been elusive. Furthermore, these concepts break down in attempts to describe the dynamics of SOC associated with horizons dominated by mineral materials.

The relative importance of aboveground sources (e.g., litterfall) and belowground sources (e.g., fine roots) of SOC is key to understanding impacts of disturbance and management on SOC. It is now understood that across many ecosystems most SOC is derived from root inputs and not aboveground inputs. In fact, root inputs may account for five times as much SOC as aboveground sources (Jackson et al. 2017). The intimate association of mineral soil and roots may be the primary cause of the disproportionate importance of roots on SOC. Historically, the focus has been on forest floor mass or litter layer depth; however, there is a growing recognition of the role of fine root production and turnover as OM inputs. This knowledge will have important implications for our ability to predict the response of SOC to disturbances that affect aboveground and belowground sources of OM.

The old paradigm suggested that OM entering the soil had three possible fates: (1) loss to the atmosphere as $\mathrm{CO}_{2},(2)$ incorporation into microbial biomass, or (3) stabilization as humic substances (Schnitzer and Kodama 1977; Tate 1987). Humic substances were described as refractory, darkcolored, heterogeneous organic compounds of high molecular weight which could be separated into fractions based on their solubility in acidic or alkaline solutions (Sutton and Sposito 2005). Advances in analytical technology have revealed that SOC is largely made up of identifiable biopolymers, and the perceived existence of humic substances was an artifact of the procedures used to extract the material (Kelleher et al. 2006; Kleber and Johnson 2010; Lehman and Kleber 2015; Marschner et al. 2008).

Predicting the long-term behavior of SOC pools is difficult when using the old paradigm. Compounds thought to be chemically recalcitrant and resistant to decomposition (e.g., lignin) sometimes turned over rapidly, whereas compounds thought to be labile (e.g., sugars) were demonstrated to persist for decades (Grandy et al. 2007; Kleber and Johnson 2010; Schmidt et al. 2011). These inconsistencies uncovered key misconceptions of the old paradigm that prevented a pre- 
dictive understanding of the vulnerability of SOC to change. As a result of such shortcomings, the conceptual model that soil scientists use to describe SOC and stabilization is undergoing a paradigm shift toward one that emphasizes the complex interactions between microorganisms and minerals in the soil.

This new paradigm for understanding SOC stability postulates that SOC exists across a continuum of microbial accessibility, ranging from free, unprotected particulate materials and dissolved OM to organic substances that are stabilized against biodegradation through association with mineral surfaces or occlusion within soil aggregates (or both) (Fig. 2.3) (Lehman and Kleber 2015). Under this paradigm, interactions of the microbial community and soil minerals, rather than characteristics inherent in the SOC itself, are the primary regulators of the pathways of $\mathrm{OM}$ stabilization and biodegradation. These factors may more accurately predict the behavior of SOC pools and are also more easily measured than molecular properties of SOC, leading to new possibilities for management.

Sorption to mineral surfaces and occlusion within aggregates are the basic mechanisms of SOC stabilization under the emerging paradigm. Whether OM is sorbed to the surface of mineral soil particles or occluded depends partly on the chemical characteristics of SOC and whether microorganisms assimilate the SOC or use it as energy. Development of the concept of substrate use efficiency (SUE; the proportion of substrate assimilated versus mineralized or respired) has found that the ability of an organism to effectively decompose and transform the structural components of OM into stabilized SOC is related not only to the chemical characteristics of SOC, but also to the composition of the soil microbial community (Cotrufo et al. 2013). When microorganisms use the decomposition products of litter for energy (low
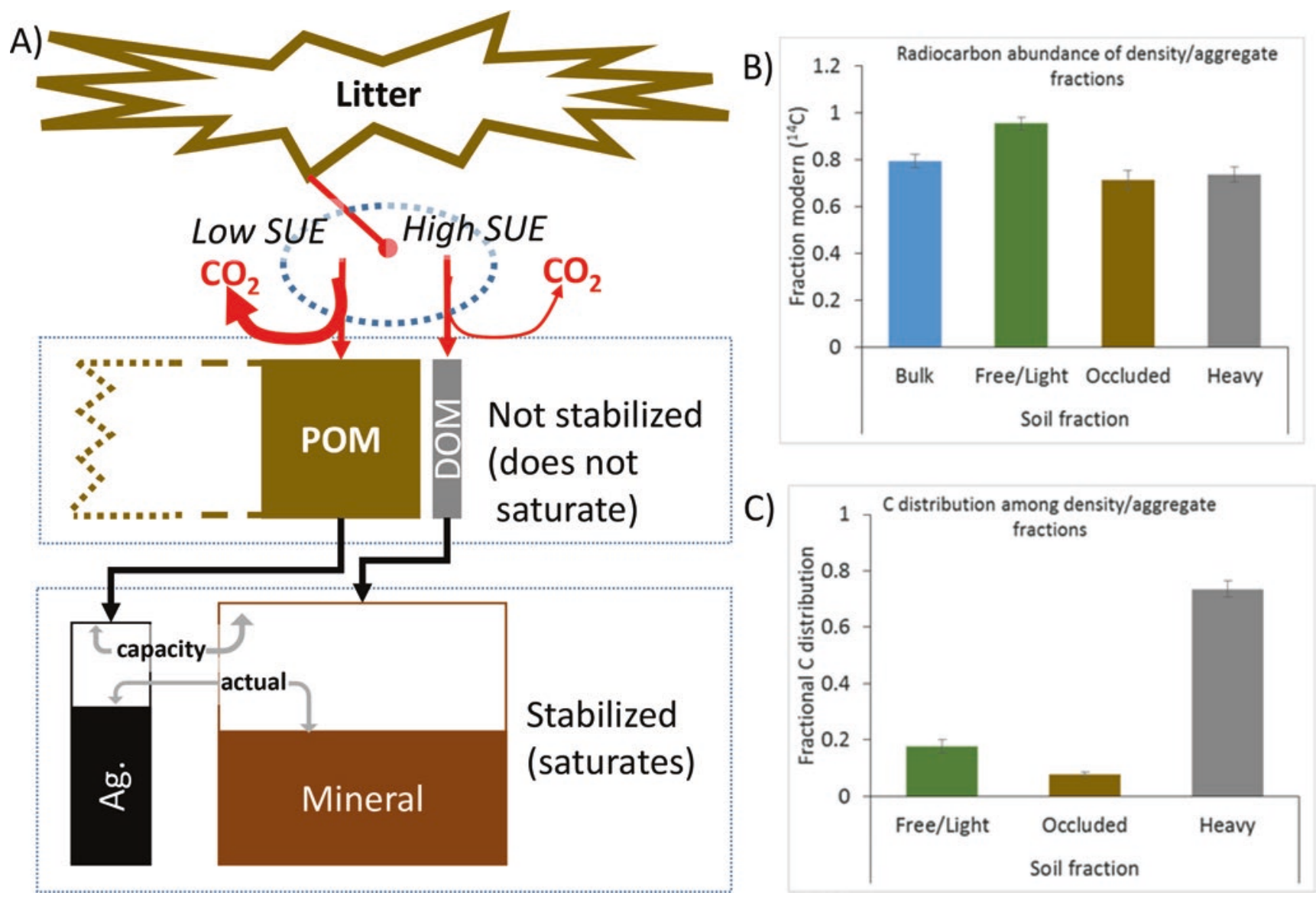

Fig. 2.3 (a) Conceptual model of emerging paradigm on soil organic carbon (SOC) stabilization. (1) SOC starts as litter that is deposited on the soil surface or belowground as senesced litter, roots, and other forms of organic matter (OM). (2) The microbial substrate use efficiency (SUE) determines whether the decomposition products of litter remain as particulate organic matter (POM) or are used to build microbial cells that eventually become dissolved organic matter (DOM). (3) POM is stabilized within aggregates (Ag.) while DOM is stabilized on mineral surfaces. (b) Radiocarbon abundance by soil fraction. These different stabilization pathways lead to different stabilities as indicated by the ${ }^{14} \mathrm{C}$ abundance. The free/light fraction is not stabilized and has the youngest age, indicating that it is rapidly cycling. The occluded and heavy fractions are stabilized, cycle more slowly, and therefore have older ${ }^{14} \mathrm{C}$ ages. (c) Distribution of $\mathrm{C}$ by soil fraction. Most soil $\mathrm{C}$ in the mineral soil is found in the heavy fraction associated with mineral surfaces 
SUE), that fraction remains as particulate OM stabilized within aggregates. Litter used for building microbial cells (high SUE) is stabilized on mineral surfaces and eventually becomes dissolved $\mathrm{OM}$ as a result of microbial exudation and death or lysis. Aggregate and mineral stabilized pools of $\mathrm{C}$ have a limited capacity and are said to saturate at a certain level. In contrast, free particulate matter is thought to have no upper threshold or a very high threshold.

Whether $\mathrm{OM}$ is stabilized within aggregates, through sorption on mineral surfaces, at depth, or in recalcitrant materials such as char, the presence of stabilized SOC is thought to be an ecosystem property: a property that arises as a result of an exchange of material or energy among different pools and their physical environment. Consequently, understanding the mechanisms that are important to the overall residence time of SOC as well as its response to a changing environment (Schmidt et al. 2011) will be valuable for monitoring and managing SOC. Further development and study of this paradigm are likely to find several interacting pathways to stabilize $\mathrm{C}$ in soils that involve microbial accessibility and chemical recalcitrance.

\section{Application of the New Paradigm to Assessing Soil Carbon Vulnerability}

Vulnerability of SOC (mineral soil and O horizons) to change refers to the susceptibility of SOC to change in the face of disturbance. Change could mean either increases or decreases, but usually the concern is with loss of SOC. Vulnerability of SOC can be described in terms of resistance and resilience (defined below). Soil C stores could resist losses as the result of a perturbation, or they could be resilient and recover SOC lost due to the perturbation. A system that is not affected by disturbance (scenario 1 in Fig. 2.4) is thought to be resistant to change. However, a system that loses SOC because of a disturbance, and regains lost SOC post-disturbance, is resilient but not resistant (scenario 2 in Fig. 2.4). In scenario 3 (Fig. 2.4), the system has not resisted the disturbance and has not recovered, so it is neither resistant nor resilient.

These concepts are important because SOC loss and recovery can affect the $\mathrm{C}$ storage of landscapes over long timescales. Thus, the implications of SOC management and response to change need to be considered on a larger scale in both geographic extent and time. Due to heterogeneity of disturbance and time since disturbance on the landscape and over time, the system that resists change (scenario 1) will store the most SOC in the landscape over time, followed by 2 and then 3. Therefore, SOC in these systems increases in relative vulnerability from 3 to 1 , with 3 being the most vulnerable to losses.

The vulnerability of SOC to change depends on the particular forcing (e.g., climate change, fire regime shift, invasive species, disturbance). Furthermore, there are usually interactions among forcing variables. For example, increased occurrence of wildfire will probably precede an ecosystem shift caused by climate change. This type of situation could result in scenario 3, where SOC is lost and not recovered. Humans could hasten these sorts of shifts in SOC content through certain management decisions, as in the case of intensive forest harvesting or grazing areas that may be susceptible to species shifts caused by climate change (Noss 2001; McSherry and Ritchie 2013).

With this new SOC paradigm comes a fresh approach to studying and predicting the response of SOC to disturbance, climate, environmental change, or management. The stability of any pool depends on the magnitude of, and controls on, its fluxes (inputs and outputs) (Fig. 2.5). The inputs are the quantity and quality of $\mathrm{C}$ fixed by the primary producers and altered by abiotic processes (e.g., fire); the outputs are regulated by microbial accessibility and microbial activity. Anything that changes the (1) quantity of OM inputs, (2) quality of OM inputs, (3) microbial accessibility, or (4)
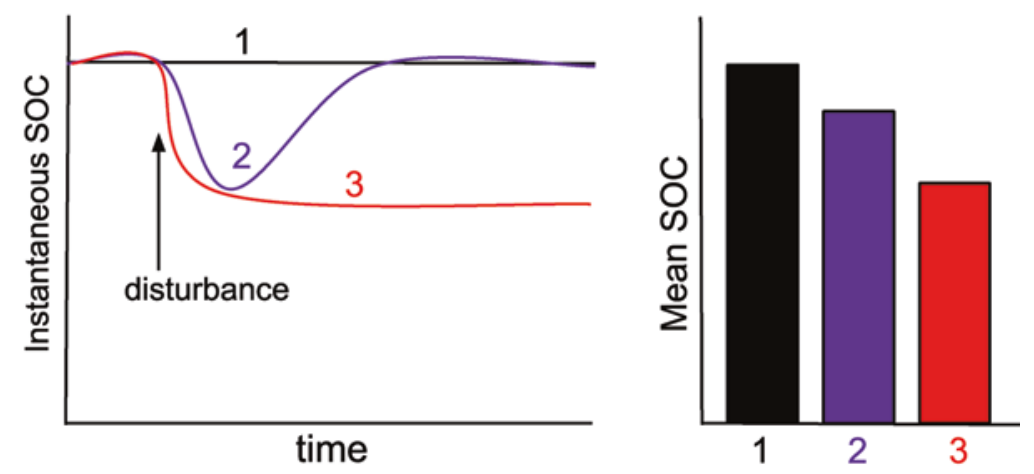

Fig. 2.4 Diagram of soil organic carbon (SOC) responses to disturbance. (a) The vulnerability of SOC to change depends on timescale, frequency and magnitude of change, and recovery. In scenario 1 , soil C is stable through time, whereas in scenarios 2 and 3 , a perturbation causes SOC to decrease. In scenario 2, SOC recovers to predisturbance levels; in scenario 3, it does not. (b) The mean SOC content over time would be highest for scenario 1, which never lost SOC, followed by 2 and 3 
Fig. 2.5 Schematic showing the soil organic carbon (SOC) pool in balance with its inputs and outputs, which are regulated by primary production, quality of inputs, controls on microbial accessibility of SOC, and microbial activity

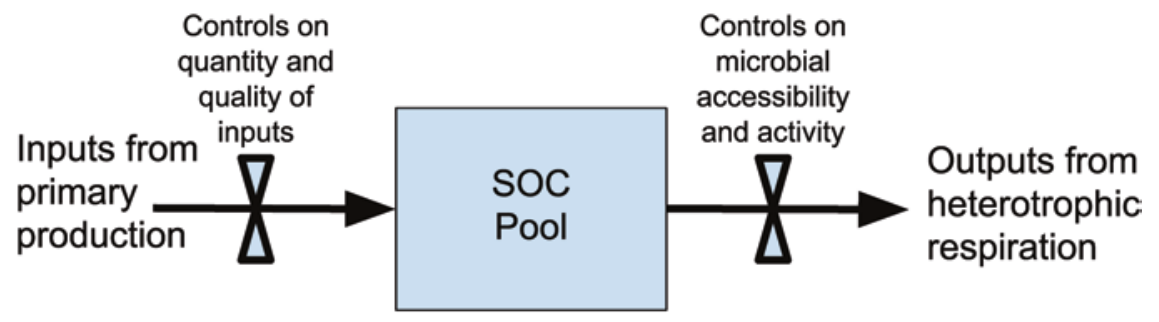

microbial activity will affect the magnitude and stability of the SOC pool. Examples of factors that could affect these inputs and outputs are listed next and will be referenced in the context of specific disturbances in the following paragraphs.

Changes affecting quantity of $\boldsymbol{O M}$ inputs - shifts in productivity; the removal or addition of biomass by fire, harvesting, or mulching

Changes affecting quality of OM inputs - change in species; changes in allocation of production (especially belowground versus aboveground production); transformation of biomass by pyrolysis

Changes affecting microbial accessibility-destruction of aggregates; destabilization of redox-active minerals; inputs of active minerals (e.g., ash deposition); changing the OC saturation state; changes to the quality and quantity of SOC inputs, which could affect priming (stimulation of decay of stabilized SOC); changes in the distribution of SOC with depth through erosion and deposition, leaching, bioturbation, and other influences

Changes affecting microbial activity - change in soil temperature and moisture, nutrient availability, freeze-thaw patterns, oxygen availability (i.e., redox), $\mathrm{pH}$, or salinity; change in nutrient status from additions of substances such as herbicide or additions of $\mathrm{N}$ and sulfur from acid deposition

\section{Soil Carbon Vulnerability Under Key Disturbances}

\section{Climate Change and Increasing Carbon Dioxide}

As a primary factor in soil formation, climate has profound effects on SOC cycling (Jenny 1941). Quantity and quality of OM inputs will be impacted as warming temperatures and shifting precipitation regimes will lead to transitions in forest and rangeland plant communities (Clark et al. 2016). Microbial accessibility may be impacted as temperature and moisture changes alter rates of mineral complexation and leaching. Finally, microbial activity itself is sensitive to changes in temperature and moisture availability. In addition to changes directly tied to climate, increases in $\mathrm{CO}_{2}$ concentration will alter plant productivity, affecting the quantity of $\mathrm{C}$ inputs to soil, as well as the relative contributions of roots and shoots to SOC, potentially increasing root-derived OM inputs (Phillips et al. 2012). Some have also shown that litter quality will change or that species shifts could take place which change the quality of $\mathrm{C}$ inputs to soil (MacKenzie et al. 2004).

Impacts of climate change on SOC have been assessed by using manipulation experiments, ecosystem modeling, and field sampling along climate gradients (climosequences). Globally, studies of soil incubations report an increased loss of SOC from bulk soil under warmer temperatures (e.g., Sierra et al. 2015). Northern latitudes are expected to bear the brunt of this loss as permafrost thaws and decomposition is amplified, as shown by soil warming experiments (Schuur et al. 2015). Despite indications of increased mineralization of SOC, coupled Earth system-climate models suggest a change in global SOC pools of -72 to $+253 \mathrm{Pg}$ (USGCRP 2018). Projections of increasing SOC with warming are primarily a result of a modeled increase in SOC of northern latitude soils, driven by the effect of increased plant productivity on $\mathrm{C}$ inputs to soil (Genet et al. 2018). Recent field experiments show that shrub expansion in tundra, a phenomenon tied to climate change, may also promote stabilization of SOC (Lynch et al. 2018). This complex response of the soil-plant system to warming highlights the importance of a multifaceted approach to understanding climate change impacts on SOC stocks.

Climosequences are an approach that may better approximate a whole-ecosystem, longer-term response of SOC to climate change than short-term incubations. There is some indication of reduced SOC in warmer areas compared to cooler areas (Lybrand et al. 2017; Wagai et al. 2008). Along a tropical forest chronosequence, there was no trend in SOC storage or stabilization across a warming temperature gradient despite large increases in plant-driven inputs (Giardina et al. 2014). These results suggest that a temperature-driven reduction in stabilized SOC could offset increases in SOC inputs projected with climate change. Such projections emphasize the need for maintaining bulk density, aeration, and other soil properties that promote aggregation and mineral-associated stabilization under a warming climate.

Carbon dioxide fertilization effects on plant growth may lead to increases in plant productivity in some ecosystems 
(Hickler et al. 2008) or changes in litter quality (e.g., Henry et al. 2005). Historically, higher productivity was thought to increase SOC stocks (Harrison et al. 1993). However, results of large-scale $\mathrm{CO}_{2}$ enrichment experiments have not shown substantial increases in SOC as a result of $\mathrm{CO}_{2}$ fertilization (Hungate et al. 1997; Schlesinger and Lichter 2001). Increased $\mathrm{C}$ inputs in these experiments were found to be disproportionately partitioned into rapidly cycling, nonstabilized SOC pools. Additionally, increases in root exudates have been shown to have a priming effect across many soils, stimulating the decay of SOC previously stabilized through mineral association (Sulman et al. 2014).

Precipitation changes may impact SOC cycling in ways independent of simply increasing or decreasing average soil moisture, with effects especially pronounced in arid and semiarid ecosystems such as grasslands and deserts. Shifts in the timing of rainfall, rather than amount alone, have been shown to alter microbial activity via enzyme and nutrient dynamics (Ladwig et al. 2015). Precipitation event size and timing, which affect soil moisture levels between events, are a strong control over microbial mineralization of $\mathrm{C}$ in arid systems (Cable et al. 2008). In addition, moving from smaller, more frequent rainfall events to fewer, larger events can increase arid grassland productivity, thus increasing inputs of organic matter to soil (Thomey et al. 2011). Although more research is needed on the topic, especially in semiarid woodlands, shifts in microbial activity and plant production due to changing rainfall patterns are likely to affect SOC storage in water-limited ecosystems. Advances in understanding precipitation impacts on SOC are nonetheless overshadowed by the great uncertainty in projections of precipitation changes (IPCC 2014).

\section{Fire}

Fire can have many effects on SOC through changing the quantity and quality of $\mathrm{C}$ inputs to soil, such as the forest floor, and affecting conditions that control microbial activity and access to SOC. Fire, whether a prescribed burn or wildfire, has important first-order effects on SOC that are tied to fire intensity and duration of heating (Neary et al. 1999). Fire that mineralizes surface OM will reduce total $\mathrm{C}$ pools (SOC plus forest floor) and OM inputs to SOC. Fires in organic soils, such as peatland, are difficult to control, can persist for long periods of time, and combust large amounts of SOC (Reddy et al. 2015). In mineral soils, at least partial consumption of the $\mathrm{O}$ horizon is common in wildfires, especially in shrubby or forested sites with high fuel loading near the surface (Neary et al. 1999). Even controlled prescribed burns can generate enough heat to consume the forest floor and reduce O horizon and SOC storage (Boerner et al. 2008; Sackett and Haase 1992; Sánchez Meador et al. 2017).

Depending on soil bulk density and parent material, soil heating is usually strongly attenuated with depth in the min- eral soil profile, and depths as shallow as $2.5 \mathrm{~cm}$ may be well buffered from SOC combustion during light surface fires (DeBano et al. 1977). Nonetheless, there is the potential for high loss of SOC via combustion during fire given high surface SOC concentrations. Soils start to lose significant SOC when soil temperatures exceed about $150{ }^{\circ} \mathrm{C}$, temperatures achievable in surface soil during many burns and at depths greater than $2.5 \mathrm{~cm}$ during a moderate- or high-intensity burn (Araya et al. 2017; Neary et al. 1999). Previous research has quantified thresholds of soil heating for loss of different chemical fractions of SOC (González-Pérez et al. 2004); however, in light of the new SOC paradigm, loss of aggregates may be a more valuable indicator for overall SOC storage postfire. In a soil-heating laboratory experiment, soils exposed to temperatures that would be expected in high-intensity, high-severity fires had proportionately less SOC stored in macroaggregates than soils exposed to low temperatures (Araya et al. 2017). Even temperatures found in low- and moderate-severity burns, if long enough in duration, can degrade soil aggregates (Albalasmeh et al. 2013). Progress in this area is still inhibited by a lack of understanding of how common measures of burn severity, such as crown or duff consumption, relate to measurable soil effects (Kolka et al. 2014).

The first-order loss of SOC via combustion may be partially offset by creation of heat-altered $\mathrm{C}$ such as soot, charcoal, or biochar, collectively known as pyrogenic $\mathrm{C}$ (pyC). However, it may be difficult to detect significant increases in pyC from just one fire. Factors controlling pyC formation and accumulation are complex and likely to vary by soil type, climate, and ecosystem (Czimczik and Masiello 2007). In a fireprone ponderosa pine (Pinus ponderosa) forest in Colorado, there was no difference in pyC content in the soil between recently burned and unburned areas, implying a role for erosion or legacy of past burns, or both, in present-day pyC content (Boot et al. 2015). In the same wildfire, postfire erosion and sedimentation were found to be an important control over spatial distribution of pyC (Cotrufo et al. 2016). DeLuca and Aplet (2008) estimate that charcoal may account for 15-20\% of the total $\mathrm{C}$ in temperate, coniferous forest mineral soils and that some forest management activities (e.g., salvage logging, thinning) may reduce soil pyC content and long-term storage.

Second-order impacts of fire on the O horizon and SOC may take longer to become manifest. These effects result from fire's direct impact on soil microbial biomass, soil chemical characteristics, and plant productivity. After high-severity wildfire, the soil microbial community can shift in composition and size, which can impact microbial SOC transformations (Knelman et al. 2017; Prieto-Fernández et al. 1998). Fireinduced increases in soil $\mathrm{pH}$ and an initial increase in $\mathrm{N}$ availability can also affect microbial activity and mineralization of the O horizon and SOC (González-Pérez et al. 2004; Hanan et al. 2016; Kurth et al. 2014; Raison 1979). A darkening of the surface and decrease in surface albedo can raise soil temperatures, increasing SOC mineralization rates. Loss of vegetation 
can reduce the forest floor. The bare soil surface is left vulnerable to erosion, exposing deeper SOC for decomposition and loss as $\mathrm{CO}_{2}$. However, it is unclear whether postfire erosion could increase SOC sedimentation enough to outweigh $\mathrm{CO}_{2}$ losses (Cotrufo et al. 2016; Doetterl et al. 2016). A meta-analysis found that 10 years postfire, SOC increased across multiple forested sites, which could be attributed to a combination of secondary effects and pyC creation (Johnson and Curtis 2001). In areas that have repeated burning, these secondary fire effects accumulate over decades, with net effects on SOC that may vary by ecosystem type. A recent meta-analysis found an overall increase in SOC in frequently burned forests, yet a decrease in SOC in frequently burned grasslands (Pellegrini et al. 2017). These changes are thought to be largely tied to effects of fire on nutrient availability and plant productivity. Organic soils may lose exceptionally large amounts of $\mathrm{C}$ due to indirect effects of wildfire. In permafrost soils, wildfire increases the active layer depth, ultimately leading to increased $\mathrm{C}$ loss as $\mathrm{CO}_{2}$ in the long term (Zhang et al. 2015a, b).

To understand the role that management can play in fireSOC dynamics, we can consider how the reported effects are linked to fire behavior, which depends on fuel loading, weather, and topography. For example, slash piles can generate extremely high soil temperatures when burned. These temperatures, which are higher than typical broadcast burns, lead to chemical and microbial community transformations with potential feedbacks to SOC processing (Esquilín et al. 2007; Massman and Frank 2005). Slash piles in ponderosa pine forest in Arizona were found to have lower SOC in the top $15 \mathrm{~cm}$ of mineral soil 7 months after burning (Korb et al. 2004). However, high soil moisture and reduced bulk density near the surface can decrease surface heating (Frandsen and Ryan 1986).

\section{Sidebar 2.2 Positive and negative effects of pyrogenic carbon on soils}

\begin{tabular}{l|l}
\hline Positive & Negative \\
\hline Carbon sequestration & $\begin{array}{l}\text { Toxicity to plants, microbes, } \\
\text { soil animals, invertebrates } \\
\text { Carrier of contaminants }\end{array}$ \\
\hline $\mathrm{CO}_{2}$ capture & Carbon fluxes \\
\hline $\begin{array}{l}\text { Improving aggregate stability } \\
\text { ander holding capacity }\end{array}$ & Heavy metals \\
\hline $\begin{array}{l}\text { Stabilization of contaminants } \\
\text { pollutants }\end{array}$ & Altering soil pH \\
\hline Catalyst for microbes & Organic chemical release \\
\hline
\end{tabular}

Pyrogenic C (i.e., char, biochar, black carbon) may not exactly follow the emerging paradigm of SOC stabilization. Pyrogenic $\mathrm{C}$ is the product of incomplete combustion of OM and fossil fuels (see Chap. 7) and exists along a continuum of increasing alteration relative to its original OM from char to soot. It has been found that pyC can persist in soils and sediments for centuries to millennia and so is thought to be resistant to degradation. In addition, pyC affects many factors important for SOC stabilization. It increases cation exchange capacity (Liang et al. 2006), promotes water and nutrient retention, and reduces soil bulk density, encouraging microbial activity. Pyrogenic $\mathrm{C}$ is also highly utilized by ectomycorrhizal fungi (Harvey et al. 1976). The mechanism by which pyC resists degradation is thought to result from its complex molecular structure of condensed aromatic rings. However, pyC is often found in association with mineral surfaces and within soil aggregates (Brodowski et al. 2006; Wagai et al. 2009), suggesting that it may promote these stabilization processes, which in turn allow it to resist decomposition. We currently lack nationwide estimates of pyC in soil, although a recent global analysis estimated that pyC represents about $14 \%$ of total SOC (Reisser et al. 2016).

The first-order loss of SOC via combustion may be partially offset by creation of heat-altered $\mathrm{C}$ such as soot, charcoal, or biochar, collectively known as pyrogenic C (pyC). However, it may be difficult to detect significant increases in pyC from just one fire. Factors controlling pyC formation and accumulation are complex and likely to vary by soil type, climate, and ecosystem (Czimczik and Masiello 2007). In a fireprone ponderosa pine (Pinus ponderosa) forest in Colorado, there was no difference in pyC content in the soil between recently burned and unburned areas, implying a role for erosion or legacy of past burns, or both, in present-day pyC content (Boot et al. 2015). In the same wildfire, postfire erosion and sedimentation were found to be an important control over spatial distribution of pyC (Cotrufo et al. 2016). DeLuca and Aplet (2008) estimate that charcoal may account for 15-20\% of the total $\mathrm{C}$ in temperate, coniferous forest mineral soils and that some forest management activities (e.g., salvage logging, thinning) may reduce soil pyC content and long-term storage.

\section{Harvesting and Thinning}

Forest operations, such as harvesting and thinning, alter SOC by reducing $\mathrm{C}$ input quantity via forest floor and root $\mathrm{OM}$ inputs as the stand regenerates. In addition, microbial accessibility and activity are altered through the disturbance of the soil surface, which changes temperature and moisture regimes.

As a result of high heterogeneity in SOC, it can be exceedingly difficult to detect change as a result of forest harvesting in any specific study. The results of many individual experiments are synthesized in meta-analyses and can be used to detect changes that are broadly consistent across studies, 
even when heterogeneity obscures treatment effects within a single study. A few meta-analyses and review articles conclude that the net effect of harvest is a reduction in SOC, with forest and soil type determining the magnitude of $\mathrm{C}$ loss (Jandl et al. 2007; Johnson and Curtis 2001; Nave et al. 2010). Nave and others (2010) reported an $8 \%$ average reduction in SOC stocks after harvesting over all forest and soil types studied. Even whole-tree harvesting (but leaving roots in the soil) for biomass production may have little longterm effect on mineral SOC stocks if $\mathrm{O}$ horizons are left undisturbed (Jang et al. 2016; Powers et al. 2005). In general, postharvest reductions in SOC have been shown to occur as a result of soil disturbance during harvesting and site preparation (Achat et al. 2015a, b; James and Harrison 2016). However, advances in the understanding of how harvesting impacts belowground processes are difficult because most studies focus on the first $30 \mathrm{~cm}$ of the soil profile or even just the forest floor. Harrison and others (2011) report that for a variety of ecosystems and treatments, valid estimation of changes in ecosystem $\mathrm{C}$ was not even possible without sampling soil deeper than $20 \mathrm{~cm}$. Therefore, these losses are primarily the result of a reduction in litter layer mass and organic matter inputs from growing trees; they may also reflect the sampling challenges of accurately tracking forest floor C over time (Federer 1993; Yanai et al. 2000).

Thinning of forest stands, as opposed to harvesting for timber, is a common practice to achieve various silvicultural objectives. Effects of thinning on inputs to SOC are variable, depending on residue management. Residues of the thinning process include the main parts of the cut trees: bole, branches, leaves, and the associated roots that have been severed. All of these components have a trajectory toward decomposition, which is, in general, accelerated due to the physical disturbance. Varying the timing (Schaedel et al. 2017) or intensity (D'Amore et al. 2015) of thinning may mitigate C losses. Forest thinning and competition control have a much smaller impact on soil characteristics and therefore affect SOC stocks less than forest biomass harvesting operations. Protection of natural forests through the use of intensively managed forests may also provide the benefit of $\mathrm{C}$ sequestration (Ouimet et al. 2007) or result in a release of $\mathrm{C}$ to the atmosphere (Harmon et al. 1990). Furthermore, herbicide application to improve seedling growth has been shown to have a positive impact on $\mathrm{C}$ storage aboveground but a negative impact on belowground C (Markewitz 2006).

Biomass harvesting and removal of woody residues by burning or for bioenergy are a concern in many forest ecosystems because of the potential adverse impacts on productivity (Janowiak and Webster 2010), ectomycorrhizae (Harvey et al. 1976), long-term nutrient cycling (Harmon et al. 1994), soil moisture content (Maser et al. 1988), $\mathrm{N}_{2}$ fixation (Jurgensen et al. 1987), and regeneration success (Schreiner et al. 1996). Harvey and others (1981) noted that harvesting has the potential to disturb soils and reduce the amount of woody residues, particularly in dry forest types. However, several studies have shown that coarse wood retention has very little effect on SOC or nutrients (Busse 1994), perhaps because all soils have been affected by coarse wood at some time (Spears et al. 2003). However, coarse wood functions as a $\mathrm{C}$ storage pool, creates wildlife forage areas, enhances fungal diversity, provides erosion control, and increases moisture retention. In addition, if soils have very low buffering capacity due to soil parent material chemistry and historical impacts of atmospheric deposition, biomass harvesting reduces the total amount of nutrients left on-site. Nutrient removal is particularly marked on sites that are extremely nutrient limited as a result of long-term anthropogenic acidification, overgrazing, wildfire, or excess OM piling and burning. Understanding inherent soil chemistry and composition, resilience to nutrient losses, and ecosystem dynamics dependent on nutrient cycling throughout a rotation or longer is necessary for assessing long-term sustainability (Jang et al. 2015).

\section{Livestock Grazing}

Rangelands, despite their lack of forest floor, can contain high amounts of SOC because grasses allocate a high percentage of biomass to roots. Rangeland SOC stocks are related to plant productivity, but management activities can have important effects on SOC stocks (Silver et al. 2010). Grazing by livestock can influence numerous factors that have control over SOC content with complex interactions that make it difficult to predict the net effect on SOC. Directly, grazing influences the quantity of OM that returns to the soil. Indirectly, grazing affects $\mathrm{OM}$ quality by altering plant physiology and ecological processes. Secondary feedbacks can occur if nutrient removal through grazing reduces grassland productivity.

Studies show that grazing rate, duration, and intensity can interact with wind erosion, site properties, and restoration activities to cause both increases and decreases in SOC (Piñeiro et al. 2010). Herbivores alter the quality of OM inputs by reducing $\mathrm{C} / \mathrm{N}$ ratios of plant shoots and roots. Lower $\mathrm{C} / \mathrm{N}$ ratios in plant litter increase decomposition rates and net $\mathrm{N}$ mineralization by reducing microbial demand for $\mathrm{N}$; that is, $\mathrm{N}$ stocks are high enough to promote mineralization despite immobilization through microbial assimilation (Frank and Groffman 1998). These changes in decomposition rates suggest that microbial activity and substrate use efficiency are changed and that while decomposition rates may increase a return of $\mathrm{CO}_{2}$ to the atmosphere, a portion of the $\mathrm{C}$ will return to the soil in dissolved forms that may be stabilized on mineral surfaces.

Grazing management techniques intended to increase forage production may also increase the quantity of inputs to 
SOC, thus accumulating atmospheric $\mathrm{C}$ as a $\mathrm{C}$ sink (Conant et al. 2001). Nitrogen is typically the nutrient limiting primary production in grasslands and thus SOC content (Piñeiro et al. 2010). Maintenance of SOC is possible with grazing management systems that maintain $\mathrm{N}$ content and grassland productivity. High stocking rates tend to lead to decreased production (Conant et al. 2001), so systems such as slow rotation grazing with moderate stocking levels will increase vegetative heterogeneity and increase soil aggregate stability (Conant and Paustian 2002; Fuhlendorf and Engle 2001).

Soil stability is important for aggregation and microbial accessibility of SOC. Grazing can increase rates of erosion, which exports SOC from a site. Indeed, grazing in arid and semiarid systems can lead to a destabilization of soil surfaces that subsequently leads to losses of soil nutrients to wind and water erosion (Neff et al. 2005). Losses in soil nutrients can lower fertility, which can reduce plant productivity. As with postfire erosion, however, it is unclear whether this process increases sedimentation rates that outweigh other losses.

Local adaptations of grazing systems have been shown to increase net primary productivity, $\mathrm{N}$ storage, and, as a result of these pathways, SOC storage (Piñeiro et al. 2010). Abrupt changes in intensity in grazing systems ultimately reduce net C storage in soils by the alteration of plant communities through the direct action of grazing. When slow-growing native plants adapted to low disturbance are intensively grazed, SOC is lost through the alteration of plant roots, N availability, decomposition of plant litter, and the control of the soil microbial community (Klumpp et al. 2009).

The response of SOC to grazing depends on multiple factors: climate, soil properties, landscape position, plant community composition, and grazing management practices (Piñeiro et al. 2010; Reeder and Schuman 2002). Considering the sensitivity of rangelands to seasonal drought, for example, can help predict impacts of grazing on SOC stocks. Southwestern rangelands are particularly sensitive to drought; annual net $\mathrm{C}$ loss is a common occurrence due to low grassland productivity during drought years (Svejcar et al. 2008). In these instances, managers may reduce grazing intensity during drought periods to ensure recovery of grassland productivity the following year. The effects of reduced stocking rate on SOC in rangelands remain highly uncertain, however, and data are lacking in arid southwestern systems (Brown et al. 2010).

\section{Nutrient Additions}

The addition of fertilizing nutrients to mineral soils, through either nutrient management or $\mathrm{N}$ deposition (acid rain), can result in gains, losses, or no change in SOC stocks; the outcome depends on a large number of factors, not all of them known (Blagodatskaya and Kuzyakov 2008; Jandl et al.
2007; Janssens et al. 2010). Forest fertilization has been shown to increase or decrease SOC by increasing productivity, shifting production to aboveground vegetation components, increasing SOC mineralization rates, and depressing certain enzyme activity (Jandl et al. 2007; Van Miegroet and Jandl 2007). Effects of forest fertilization on SOC have been found to be site specific, but most studies show an increase in SOC stocks (Johnson and Curtis 2001).

Agroforestry may also benefit from planting $\mathrm{N}$-fixing shrubs and trees as an economical $\mathrm{N}$ source for crops (Danso et al. 1992). Nitrogen-fixing tree species are associated with higher forest SOC; accumulation of SOC has been reported to be about $12-15 \mathrm{~g}$ of $\mathrm{C}$ for every gram of $\mathrm{N}$ fixed (Binkley 2005). The mechanisms leading to this SOC increase are incompletely understood but are thought to differ from the direct effects of $\mathrm{N}$ fertilization (Binkley et al. 2004; Forrester et al. 2013). Research suggests that OM derived from the $\mathrm{N}$-fixing Acacia species is more protected from decomposition than litter from other trees in mixed stands (Forrester et al. 2013). Most research on the subject has been conducted outside of the United States; more studies are needed that focus on $\mathrm{N}$-fixing trees, such as Alnus species, and forest management practices specific to the United States.

On a global scale, the largest source of nutrient additions to forest soils is atmospheric $\mathrm{N}$ deposition derived from both natural and anthropogenic sources. Anthropogenic N, from fossil fuel combustion and recirculated cropland fertilizers, accounts for about $60 \%$ of the approximately $130 \mathrm{Tg}$ of $\mathrm{N}$ deposited globally each year (Kanakidou et al. 2016). Chronic $\mathrm{N}$ addition experiments consistently show that SOC increases under higher $\mathrm{N}$ availability (Frey et al. 2014). This result has been attributed to greater productivity due to the fertilization effect, as well as reductions in OM decomposition. Frey and others (2014) found that in addition to more C stored in tree biomass, there were significant shifts in SOC chemistry due to shifts in the microbial community (fewer fungi). Increases in SOC were attributed to a reduction in decomposition rate due to the lower abundance of fungi in the soil.

\section{Tree Mortality}

Carbon stocks in the forest floor and soil may be impacted when high levels ( $>50 \%$ canopy loss) of tree mortality result, such as that caused by drought and bark beetles (subfamily Scolytinae) in Western US pine and spruce (Abies spp.) forests and by invasive pests (detailed in the next section). Mass tree mortality effects on SOC are similar to effects of harvesting, but with the following important differences: (1) Mortality occurs more slowly than most harvesting operations; (2) mortality events do not usually kill as many trees as are harvested in a typical operation; and (3) dead trees are 
commonly in place throughout the mortality event, although some limited postmortality harvesting is conducted in highuse areas (e.g., national forest campgrounds).

Mortality events result in a reorganization of detritus over multiple years, impacting OM inputs to SOC formation (Edburg et al. 2012). Root OM inputs to the soil may increase as trees die but may later decline due to reduced live tree density; as a result, microbial activity in the rhizosphere is altered after tree mortality (Warnock et al. 2016). Litterfall is expected to increase in the first few years following mortality as dead trees drop their needles and fine branches; afterward, litterfall will decline, reducing forest floor mass in the longer term (Zhang et al. 2015b). Longer-term inputs to the soil are larger branches and boles, as wind topples standing dead trees throughout the next decade and beyond. Thus, mortality will change the rate and type of OM matter input to the soil. Shifts in nutrient dynamics could alter SOC mineralization rates, as soil-extractable $\mathrm{N}$ levels increase and SOC/N ratios decrease (Clow et al. 2011; Morehouse et al. 2008; Trahan et al. 2015). Finally, changes in microclimate postmortality, brought about by canopy loss and decreases in transpiration, could impact detrital $\mathrm{C}$ processing (Berryman et al. 2013). The duration of these effects depends on how fast the remaining living trees expand their canopies to compensate for the loss of the overstory.

As a result of this reorganization of detritus, some changes in SOC cycling have been detected following mortality events. Evidence from stable isotopes suggests shifts in $\mathrm{C}$ substrate type used for root and heterotrophic respiration starting in the first year after tree mortality (Maurer et al. 2016). Some studies have reported decreases in microbial biomass $\mathrm{C}(\mathrm{MBC})$ and increases in the aromaticity of dissolved organic C (DOC) in the soil, which may impact SOC stabilization (Brouillard et al. 2017; Kaňa et al. 2015; Trahan et al. 2015). Despite these changes in SOC substrates and cycling rates, changes in SOC stocks following tree mortality events are often undetectable and, on average, minor compared to impacts on soil respiration, DOC, and MBC (Morehouse et al. 2008; Zhang et al. 2015b). This suggests that though individual process rates may be affected by tree mortality, the balance between inputs to and outputs from the SOC pool may be constant enough to lead to undetectable changes in SOC.

Changes in SOC may be difficult to detect because they could be highly dependent on the amount of tree mortality. In bark beetle-impacted lodgepole pine (Pinus contorta) forests of Colorado, soil respiration 8 years after mortality depended on the relative amount of living versus dead trees (Brouillard et al. 2017). However, plot-level impacts of biotic disturbance may not scale predictably to the forest or watershed. Measured plot-level increases in extractable N and DOC following a bark beetle outbreak, for example, were not detected at the watershed scale in the Rocky Mountains in Colorado (Clow et al. 2011; Rhoades et al. 2017). This result suggests that landscape-scale patchiness in outbreaks could be important for buffering negative effects of mortality on SOC.

\section{Invasive Species}

Invasive species can alter nutrient and C cycling, as well as soil physical properties, all of which can affect SOC stocks. Exotic invasions impact factors important for OM quantity and quality and microbial activity, such as nutrient mineralization, N-fixation by soil bacteria, mycorrhizal inoculation, decomposition and aeration of soils by earthworms (suborder Lubricina), and aggregation of soils by fungi (Wolfe and Klironomos 2005).

The function of many ecosystems depends on regular disturbance, for example, to foster plant renewal and regeneration, but disturbance can also be detrimental by promoting invasion of nonnative and weedy plants (Hobbs and Huenneke 1992). Initial invasiveness is caused by chronic disturbance which disrupts the native nutrient and OM cycling that increases plant nutrient availability (Norton et al. 2007). In grasslands, disturbance and subsequent weed invasion can be caused by either temporary increases in nutrients or reduced competition from plant canopies and roots (Hobbs and Huenneke 1992), although the research is still unclear about the relative importance of these processes.

Several hypotheses have been offered to explain why exotic plants are so successful in disturbed ecosystems: (1) inherent properties of the invading plant (such as earlier colonization than native vegetation); (2) vegetation factors (such as species composition, richness, and heterogeneity); (3) soil microbial dynamics; and (4) climate factors such as rainfall amount and timing, aridity, and humidity (Blank and Sforza 2007). In the absence of disturbance, there are other factors such as plant-fungal interactions that may alter soil nutrient dynamics (Brundrett 2009) and contribute to understory plant invasion (Jo et al. 2018). Arbuscular mycorrhizaldominant forests, which are characterized by thin litter layers and a low soil $\mathrm{C} / \mathrm{N}$ ratio relative to ectomycorrhizal-dominant forests, are invaded by exotic plants to a greater extent (Jo et al. 2018). Other factors that may influence the invasion of exotic plants may be more indirect, for example, external factors such as deer (Odocoileus spp.) browsing or earthworm invasion (Nuzzo et al. 2009).

Plant invasion leads to a shift in plant species composition, which can influence ecosystem properties such as $\mathrm{N}$ accumulation and cycling, SOC storage, water availability and runoff, and disturbance regime (Mack et al. 2001). Nitrogen cycling may be a particularly sensitive indicator of changes in species composition, and changes to $\mathrm{N}$ cycling are prevalent during biological species invasions (Ehrenfeld 2003; Mack et al. 2001). The impacts of nonnative plant species on SOC are largely system- and plant-dependent. Scott and others (2001) and Ehrenfeld and others (2001) found increased SOC 
under invasive grasses and shrubs in a grassland and deciduous forest, respectively. These changes in SOC were attributed to higher inherent productivity of the invasive species relative to the native vegetation. On the other hand, Bradley and others (2006) found no change in SOC pools as a result of cheatgrass (Bromus tectorum) invasions in shrublands of the western United States. Invasive cogongrass (Imperata cylindrica) in the southeastern United States has higher litter decomposition rates than native vegetation, which has implications for SOC production and turnover (Holly et al. 2009).

Earthworms increase fragmentation and decomposition of litterfall and contribute to the formation of mull humus types, in which organic surface layers are mixed into the mineral soil. Therefore, they play an important role in $\mathrm{C}$ and $\mathrm{N}$ cycling in forest soils. However, exotic earthworms from Europe and Asia have invaded recently glaciated soils in northern temperate forests in North America (Alban and Berry 1994; Dymond et al. 1997; Scheu and Parkinson 1994). These novel soil engineers are affecting SOC and nutrient dynamics (Burtelow et al. 1998; Groffman and Bohlen 1999), including a loss of C from the soil profile (Alban and Berry 1994; Langmaid 1964). Invasive earthworms can eliminate the forest floor, decrease $\mathrm{C}$ storage in the upper soil mineral horizons, and reduce the soil C/N ratio (Bohlen et al. 2004).

Invasive forest pests and diseases alter ecosystem functioning of the forest, potentially leading to effects on SOC. Some exotic pests eventually cause forest mortality (see previous section), but many result in lesser disturbance than mortality events by affecting only a few trees or by causing defoliation without killing the tree. Recently, insects have expanded into previously climatically restricted geographic areas, and their activity induces a change in $\mathrm{C}$ sequestration (Kretchun et al. 2014).

Although invasive pests are relatively common in temperate forests, their effect on $\mathrm{C}$ pools is poorly understood. Studies on catastrophic disturbances from wildfire or clearcutting indicate a substantial loss of aboveground and belowground C (Amiro et al. 2006; Humphreys et al. 2006; Thornton et al. 2002). These results are similar to a study conducted in the Pine Barrens of New Jersey, where defoliation by the gypsy moth (Lymantria dispar) reduced C storage at the landscape scale (Clark et al. 2010). Modeled infestations of hemlock woolly adelgid (Adelges tsugae) indicate that, with inputs of dead wood and roots, mineral soil and forest floor $\mathrm{C}$ pools may remain static or increase in the long term (Krebs et al. 2017). In addition, modeled invasive gypsy moth defoliation episodes indicate a shift in overstory species, but not a decrease in SOC in the short term (Kretchun et al. 2014). Similarly, in New Hampshire, where emerald ash borers (Agrilus planipennis) attacked a mixed hardwood forest, there were no short-term changes in soil microclimate, respiration, or methane oxidation under the trees; these results were attributed to the sandy soil, which diffused soil responses (Matthes et al. 2018). There are scant data on many plant, animal, insect, and pathogen invasive species, their impact on SOC, and how managers can effectively change land management to alter invasive species effects on ecosystem services. The impact of invasive pests on SOC is likely to be site- and species-specific. Soil scientists will play a key role in quantifying these impacts by measuring changes in SOC during land management or after insect outbreaks.

\section{Managing for Soil Organic Carbon in Forests and Rangelands}

As previously mentioned, SOC is critical for maintaining a host of ecosystem services. It is vulnerable to loss through events, either natural or human-induced, that remove large amounts of soil or OM inputs to soil, such as the forest floor or plant biomass (Table 2.1). Certain management actions

Table 2.1 Loss or gain in soil organic carbon (SOC) from key disturbances in forests, rangelands, and wildlands

\begin{tabular}{|c|c|c|c|}
\hline Disturbance type & $\begin{array}{l}\text { Direction of } \\
\text { SOC effect }\end{array}$ & $\begin{array}{l}\text { Magnitude } \\
\text { of SOC } \\
\text { effect }\end{array}$ & References \\
\hline $\begin{array}{l}\text { Biotic } \\
\text { disturbance } \\
\text { (insects, disease) }\end{array}$ & Loss & $\begin{array}{l}2 \% \\
(+/-1 \%)\end{array}$ & $\begin{array}{l}\text { Zhang et al. } \\
(2015 a, b)\end{array}$ \\
\hline Wildfire & $\begin{array}{l}\text { Loss } \\
(<10 \text { years }) \\
\text { Gain } \\
(>10 \text { years })\end{array}$ & $\begin{array}{l}0-4 \% \\
\text { Long-term } \\
\text { gain of } 8 \%\end{array}$ & $\begin{array}{l}\text { Johnson and } \\
\text { Curtis (2001) and } \\
\text { Page-Dumroese } \\
\text { and Jurgensen } \\
\text { (2006) }\end{array}$ \\
\hline Windthrow & $\begin{array}{l}\text { Gain in pit } \\
\text { or mound } \\
\text { area }\end{array}$ & $28 \%$ & $\begin{array}{l}\text { Bormann et al. } \\
(1995)\end{array}$ \\
\hline Hurricane & Gain & $9 \%$ & $\begin{array}{l}\text { Sanford et al. } \\
\text { (1991) }\end{array}$ \\
\hline Prescribed fire & Loss & $0-1 \%$ & $\begin{array}{l}\text { Boerner et al. } \\
\text { (2008) and } \\
\text { Sánchez Meador } \\
\text { et al. (2017) }\end{array}$ \\
\hline $\begin{array}{l}\text { Thinning and } \\
\text { burning }\end{array}$ & Gain & $2 \%$ & $\begin{array}{l}\text { Sánchez Meador } \\
\text { et al. (2017) }\end{array}$ \\
\hline Warming & Loss & $1-8 \%$ & $\begin{array}{l}\text { Dieleman et al. } \\
\text { (2012) and Lu } \\
\text { et al. (2013) }\end{array}$ \\
\hline Harvesting & $\begin{array}{l}\text { Loss } \\
\text { Gain }\end{array}$ & $\begin{array}{l}8 \% \\
(+/-3 \%) \\
8 \% \\
(+/-8 \%)\end{array}$ & $\begin{array}{l}\text { Johnson and } \\
\text { Curtis (2001) and } \\
\text { Nave et al. (2010) }\end{array}$ \\
\hline $\begin{array}{l}\text { Grazing } \\
\text { (conversion to } \\
\text { improved) }\end{array}$ & Gain & $\begin{array}{l}1-7 \% \text { per } \\
\text { year }\end{array}$ & $\begin{array}{l}\text { Chaplot et al. } \\
\text { (2016) and } \\
\text { Minasny et al. } \\
(2017)\end{array}$ \\
\hline $\begin{array}{l}\text { Woody } \\
\text { encroachment } \\
\text { into grasslands }\end{array}$ & Gain & $\begin{array}{l}1 \% \text { per } \\
\text { year }\end{array}$ & Neff et al. (2009) \\
\hline
\end{tabular}


post-disturbance can counteract such losses. Application of organic amendments such as biochar or simply leaving harvest residues in place can nearly double existing SOC (Achat et al. 2015a, b; Liu et al. 2016; Page-Dumroese et al. 2018). Shifting land management priorities to place more value on $\mathrm{C}$ management practices may help encourage best practices for building up SOC pools on forest and rangeland sites.

Fuels management that aims to reduce the risk of highseverity wildfire could help mitigate SOC losses (PageDumroese and Jurgensen 2006; Neary et al. 1999). Prescribed fire is a common fuels reduction treatment on many federal lands. During prescribed fires, managers can control fire intensity and severity to reduce the amount of $\mathrm{C}$ that will be released into the atmosphere as $\mathrm{CO}_{2}$ and increase the conversion of wood to pyC. One way to control burn intensity is by lowering fuel loadings on the soil surface before a prescribed burn. Slash pile size, season of burning, and soil texture and moisture will all determine the amount of SOC remaining in the soil after a prescribed burn (Busse et al. 2014).

Land managers are likely to have few options for sequestering SOC during a wildfire, but active management on forest lands can reduce the intensity and severity of fires. By using mechanical practices such as thinning, masticating, chipping, and mowing to reduce wildfire hazard, managers can restore healthy forests, limit damage from wildfire, and alter $\mathrm{C}$ storage. However, the loss of total site $\mathrm{C}$ during fuel treatments will negate any fire-prevention benefits if the site is unlikely to burn anyway. Therefore, risk for high-severity fire should be weighed against $\mathrm{C}$ removal benefits if maintaining ecosystem $\mathrm{C}$ over landscapes for the long term is the goal (Boerner et al. 2008; Krofcheck et al. 2017). Secondorder negative impacts of high-severity fire on SOC can be mitigated by taking action to reduce postfire erosion and speed up the regrowth of vegetation postfire. Mulching treatments slow soil erosion and have the extra benefit of adding C to the mineral soil (Berryman et al. 2014; Robichaud et al. 2013).

In the short term, thinning forest stands reduces the amount of OM inputs and thus SOC storage (Jandl et al. 2007); it also changes the microclimate and therefore decomposition of OM inputs. Forest floor decomposition is temporarily stimulated because of warmer and wetter soil conditions, and SOC may decrease (Piene and Van Cleve 1978). Although forest thinnings can reduce $C$ pools in the forest floor and mineral soil (Vesterdal et al. 1995), the overall effect on SOC may be rather small (Johnson and Curtis 2001). Whole-tree harvesting may have a greater impact on $\mathrm{C}$ reserves than thinnings or cut-to-length harvesting. However, 5 years after clear-cutting and OM removal on the Long-Term Soil Productivity study sites, there were no changes in SOC (Sanchez et al. 2006). These results highlight the resilience of some soils to harvest-induced losses of $\mathrm{C}$ and the importance of leaving roots and stumps on-site after harvesting to help maintain SOC (Powers et al. 2005). This means that best management practices for harvesting should take into consideration soil texture, climatic regime, and inherent OM levels. In addition to selecting the most appropriate harvest methods, site preparation method selection can help improve SOC. Increasing the intensity of site preparation (e.g., soil mixing, stump pulling) increases SOC losses (Johannsson 1994; Nave et al. 2010; Post and Kwon 2000).

Management to reduce $\mathrm{C}$ flux from rangelands is important because rangelands are thought to have $30 \%$ of global terrestrial C stocks (Schuman et al. 2002). Many rangeland sites are dominated by near-surface $\mathrm{C}$, so one method to reduce losses is to protect the surface mineral soil by increasing plant cover to lessen wind and water erosion (Booker et al. 2013). Grazing management can also prevent vegetative state transitions (e.g., increasing or decreasing woody plants), reduce soil disturbance, and limit bare soil exposure. For example, heavy grazing can contribute to a transition from grasses and forbs to invasion of woody shrubs, which choke out grasses (Russell and McBride 2003) or provide cover for wildlife (Laycock 1991). Different results on rangeland sites are due to varying soil moisture regimes (Booker et al. 2013); therefore, best management practices must be tailored to soil texture and climatic regime.

Compared to other disturbances like wildfire and harvesting, biotic disturbance effects on SOC storage appear to be minor. Site management may have a bigger impact on SOC storage than the disturbance event itself. Removing hazard trees or harvesting beetle-killed timber for wood products or bioenergy in a system already disturbed may lead to undesirable consequences for SOC storage. Avoiding soil compaction may promote conditions that favor SOC aggregation and stabilization.

Invasive species affect SOC storage and sequestration capacities differently from native species. For example, nonnative annual grasses that dominate in former sagebrush (Artemisia spp.) ecosystems have resulted in SOC losses (Prater et al. 2006), but when woody species replace grasses, SOC increases (Hughes et al. 2006). These differences in SOC sequestration are tied to local soil moisture regimes. All invasive species are difficult to manage because there is often more than one invader, and different species have different effects on SOC pools. Therefore, management is likely to entail identifying the species and then deciding whether action is needed to control the spread of the population (Hulme et al. 2008; Peltzer et al. 2010).

Other opportunities for increasing SOC during land management can be found with the use of soil amendments. Chipping or masticating nonmerchantable wood and using this material as a mulch (rather than burning it) can maintain surface SOC. In addition, biochar created from logging residues can be used to increase SOC on forest, rangeland, or 
mine sites (Page-Dumroese et al. 2017). Biochar additions to soil also have the benefit of increasing cation exchange capacity and soil moisture, further promoting SOC formation and stabilization. Biochar may have a positive effect on soil microbial populations as well (Steinbeiss et al. 2009). Soil amendments can also increase rangeland SOC. Long-term manure additions were found to increase SOC stocks by about $18 \mathrm{Mg} \mathrm{ha}^{-1}$ in California rangelands (Owen et al. 2015).

\section{Links to Institutional Initiatives}

There is growing awareness of soils as a key mitigating influence on global $\mathrm{C}$ cycles. Soils are emerging as a point of emphasis for maximizing the natural sinks available for $\mathrm{C}$ as offsets for increasing atmospheric greenhouse gas concentrations. Careful development of management plans that consider SOC goals within each of the disturbance scenarios outlined in this chapter could have a large multiplier effect on global C storage. Recognition of the impact of small SOC gains across large areas is the first step in impacting the overall global $\mathrm{C}$ budget.

Complementary initiatives in enhancing soil health provide a focal area for both increasing production and maintaining SOC gains or at least limiting or eliminating losses of SOC. As mentioned in the Introduction, SOC is an essential component of indices developed to indicate soil health. Widespread adoption of such indices would enhance our ability to track, maintain, and improve soil health across our nation's lands. Indeed, SOC turnover is critical to productive and healthy soils, and the new SOC paradigm presented at the beginning of this chapter can also serve as a rich framework for understanding the components of a healthy soil and valuing the maintenance of SOC. The potential for soils to store $\mathrm{C}$ and mitigate climate change has recently garnered significant attention with government agencies as well as the public (Barker and Polan 2015; Leslie 2017). Accordingly, several initiatives, briefly described in the following paragraphs, have been launched in an attempt to improve our appreciation and utilization of soils in the context of food security and climate change.

The "4 per 1000" Initiative (https://www.4p1000.org/) aims to increase SOC content through implementation of sustainable agricultural practices and thereby draw down atmospheric $\mathrm{CO}_{2}$ concentrations. This program was launched by France in 2015 at the COP 21 (the 21st Conference of the Parties, held by the United Nations Framework Convention on Climate Change).

The National Soil Health Action Plan (https://soilhealthinstitute.org/) lays out strategies and best practices for safeguarding and enhancing the vitality and productivity of soils. This plan was drawn up for the United States by the
Soil Health Institute, an independent, multipartner organization. The plan was developed over 4 years with input from agronomists, government agency leaders, scientists, and nongovernmental organizations.

The Soil2026 Initiative ${ }^{1}$ seeks to improve integration of soil survey and soil laboratory data streams while incorporating digital soil mapping. The Soil2026 campaign, launched by the USDA National Cooperative Soil Survey, will produce a complete soil inventory of the United States by 2026 along with establishing standards for digital soil mapping methods.

\section{Key Findings}

- Globally, SOC is the largest terrestrial pool of C. In the United States, most of this stock is found in forests and rangelands. It is an important provider and indicator of vital ecosystem services, such as nutrient and water cycling and $\mathrm{C}$ sequestration.

- Many scientific advances have been made in the past decade that have led to a better understanding of controls over SOC stabilization. Research shows that predicting vulnerability of SOC under disturbance can be aided by considering factors related to the quantity and quality of OM inputs and soil microbial accessibility and activity.

- Both natural and human-caused disturbances have degraded SOC stocks across the United States. Climate change, overgrazing, overharvesting, and catastrophic wildfire have emerged as the greatest concerns. Effects on SOC degradation are expected to be more severe when two or more of these disturbances interact with each other.

- Careful management can partially mitigate SOC degradation as well as promote rebuilding of SOC postdisturbance. In general, actions that promote retention and growth of native vegetation (fuels management, reforestation, and invasive weed control) and leave or add organic residues on-site will increase SOC stocks.

\section{Key Information Needs}

- Climate change effects on SOC remain highly uncertain. Specifically, research is needed to better understand how expected increases in precipitation and temperature variability—rather than changes in the mean-impact SOC vulnerability.

\footnotetext{
${ }^{1}$ Lindbo, D.L.; Thomas, P. 2016. Shifting paradigms - Soil Survey 2026. [Presentation and poster]. Resilience emerging from scarcity and abundance; meeting of the American Society of Agronomy-Crop Science Society of America-Soil Science Society of America; Nov. 6-9, 2016; Phoenix, AZ.
} 
- Future research on SOC needs to measure both surface soil $(0-30 \mathrm{~cm})$ and soil deeper than $30 \mathrm{~cm}$, preferably up to at least $1 \mathrm{~m}$, including understanding the contribution of deeper roots to OM inputs to SOC.

- There are limited data on many plant, animal, insect, and pathogen invasive species, their impact on SOC, and how managers can effectively change land management to alter invasive species effects on ecosystem services.

- Estimates of changes in SOC over time are highly uncertain due to soil heterogeneity and rock content. Concentrated efforts to standardize technological and statistical solutions for dealing with uncertainty could help better constrain future SOC predictions.

- There is a lack of studies that examine how forest and rangeland management actions interact with global change phenomena (e.g., shifting plant communities, altered fire regimes) to influence SOC vulnerability.

- Most of our understanding of forest and rangeland SOC involves only a snapshot in time or very short-term (2-4 years) studies, leaving managers unable to predict longer-term impacts of decisions on SOC. Longer-term studies (longer than a rotation) of forest management effects (e.g., Adaptive Silviculture for Climate Change (Nagel et al. 2017)) are needed.

- There is a need to provide managers with the science needed to develop best management practices for enhancing SOC within the scope of the Forest Service 2012 Planning Rule (USDA FS 2012).

\section{Literature Cited}

Achat DL, Fortin M, Landmann G et al (2015a) Forest soil carbon is threatened by intensive biomass harvesting. Sci Rep 5(1):15991

Achat DL, Deleuze C, Landmann G et al (2015b) Quantifying consequences of removing harvesting residues on forest soils and tree growth - a meta-analysis. For Ecol Manag 348:124-141

Albalasmeh AA, Berli M, Shafer DS, Ghezzehei TA (2013) Degradation of moist soil aggregates by rapid temperature rise under low intensity fire. Plant Soil 362(1-2):335-344

Alban DH, Berry EC (1994) Effects of earthworm invasion on morphology, carbon, and nitrogen of a forest soil. Appl Soil Ecol 1(3):243-249

Amacher MC, O’Neill KP, Perry CH (2007) Soil vital signs: a new soil quality index (SQI) for assessing forest soil health. Research Paper RMRS-RP-65. U.S. Department of Agriculture, Forest Service, Rocky Mountain Research Station, Fort Collins, 12 p

Amiro BD, Barr AG, Black TA et al (2006) Carbon, energy and water fluxes at mature and disturbed forest sites, Saskatchewan, Canada. Agric For Meteorol 136:237-251

Araya SN, Fogel ML, Berhe AA (2017) Thermal alteration of soil organic matter properties: a systematic study to infer response of Sierra Nevada climosequence soils to forest fires. Soil 3:31-44
Barker, D.; Polan, M. 2015. A secret weapon to fight climate change: dirt. Wash Post, December 5

Batjes NH (2016) Harmonized soil property values for broad-scale modelling (WISE30sec) with estimates of global soil carbon stocks. Geoderma 269:61-68

Berryman E, Marshall JD, Rahn T et al (2013) Decreased carbon limitation of litter respiration in a mortality-affected piñon-juniper woodland. Biogeosciences 10:1625-1634

Berryman EM, Morgan P, Robichaud PR, Page-Dumroese D (2014) Post-fire erosion control mulches alter belowground processes and nitrate reductase activity of a perennial forb, heartleaf arnica (Arnica cordifolia). Research Note RMRS-RN-69. U.S. Department of Agriculture, Forest Service, Rocky Mountain Research Station, Fort Collins, $10 \mathrm{p}$

Binkley D (2005) How nitrogen-fixing trees change soil carbon. In: Binkley D, Menyailo O (eds) Tree species effects on soils: implications for global change. NATO Science Series IV: Earth and Environmental Sciences (NAIV, vol. 55). Springer, Dordrecht, pp 155-164

Binkley D, Kaye J, Barry M, Ryan MG (2004) First-rotation changes in soil carbon and nitrogen in a eucalyptus plantation in Hawaii. Soil Sci Soc Am J 68:1713-1719

Blagodatskaya E, Kuzyakov Y (2008) Mechanisms of real and apparent priming effects and their dependence on soil microbial biomass and community structure: critical review. Biol Fertil Soils 45(2):115-131

Blank RR, Sforza R (2007) Plant-soil relationships of the invasive annual grass Taeniatherum caput-medusae: a reciprocal transplant experiment. Plant Soil 298(1-2):7-19

Boerner REJ, Huang J, Hart SC (2008) Fire, thinning, and the carbon economy: effects of fire and fire surrogate treatments on estimated carbon storage and sequestration rate. For Ecol Manag 255:3081-3097

Bohlen PJ, Pelletier DM, Groffman PM et al (2004) Influence of earthworm invasion on redistribution and retention of soil carbon and nitrogen in northern temperate forests. Ecosystems 7(1):13-27

Booker K, Huntsinger L, Bartolome JW et al (2013) What can ecological science tell us about opportunities for carbon sequestration on arid rangelands in the United States? Glob Environ Chang 23(1):240-251

Boot CM, Haddix M, Paustian K, Cotrufo MF (2015) Distribution of black carbon in ponderosa pine forest floor and soils following the High Park wildfire. Biogeosciences 12(10):3029-3039

Bormann BT, Spaltenstein H, McClellan MH et al (1995) Rapid soil development after windthrow disturbance in pristine forests. J Ecol 83(5):747-757

Bradley BA, Houghton RA, Mustard JF, Hamburg SP (2006) Invasive grass reduces aboveground carbon stocks in shrublands of the western US. Glob Chang Biol 12(10): 1815-1822

Brodowski S, John B, Flessa H, Amelung W (2006) Aggregate-occluded black carbon in soil. Eur J Soil Sci 57:539-546

Brouillard BM, Mikkelson KM, Bokman CM et al (2017) Extent of localized tree mortality influences soil biogeochemical response in a beetle-infested coniferous forest. Soil Biol Biochem 114:309-318

Brown J, Angerer J, Salley SW et al (2010) Improving estimates of rangeland carbon sequestration potential in the US Southwest. Rangel Ecol Manag 63(1):147-154

Brundrett MC (2009) Mycorrhizal associations and other means of nutrition of vascular plants: understanding the global diversity of host plants by resolving conflicting information and developing reliable means of diagnosis. Plant Soil 320:37-77 
Burtelow AE, Bohlen PJ, Groffman PM (1998) Influence of exotic earthworm invasion on soil organic matter, microbial biomass and denitrification potential in forest soils of the northeastern United States. Appl Soil Ecol 9(1):197-202

Busse MD (1994) Downed bole-wood decomposition in lodgepole pine forests of Central Oregon. Soil Sci Soc Am J 58(1):221-227

Busse MD, Hubbert KR, Moghaddas EEY (2014) Fuel reduction practices and their effects on soil quality. General Technical Report PSW-GTR-241. U.S. Department of Agriculture, Forest Service, Pacific Southwest Research Station, Albany, $161 \mathrm{p}$

Cable JM, Ogle K, Williams DG et al (2008) Soil texture drives responses of soil respiration to precipitation pulses in the Sonoran Desert: implications for climate change. Ecosystems 11:961-979

Chaer GM, Myrold DD, Bottomley PJ (2009) A soil quality index based on the equilibrium between soil organic matter and biochemical properties of undisturbed coniferous forest soils of the Pacific Northwest. Soil Biol Biochem 41(4):822-830

Chaplot V, Dlamini P, Chivenge P (2016) Potential of grassland rehabilitation through high density-short duration grazing to sequester atmospheric carbon. Geoderma 271:10-17

Clark KL, Skowronski N, Hom J (2010) Invasive insects impact forest carbon dynamics. Glob Chang Biol 16:88-101

Clark JS, Iverson L, Woodall CW et al (2016) The impacts of increasing drought on forest dynamics, structure, and biodiversity in the United States. Glob Chang Biol 22(7):2329-2352

Clow DW, Rhoades C, Briggs J et al (2011) Responses of soil and water chemistry to mountain pine beetle induced tree mortality in Grand County, Colorado, USA. Appl Geochem J Int Assoc Geochem Cosmochem 26:S174-S178

Conant RT, Paustian K (2002) Spatial variability of soil organic carbon in grasslands: implications for detecting change at different scales. Environ Pollut 116(supplement 1):S127-S135

Conant RT, Paustian K, Elliott ET (2001) Grassland management and conversion into grassland: effects on soil carbon. Ecol Appl 11(2):343-355

Cotrufo MF, Wallenstein MD, Boot CM et al (2013) The Microbial Efficiency-Matrix Stabilization (MEMS) framework integrates plant litter decomposition with soil organic matter stabilization: do labile plant inputs form stable soil organic matter? Glob Chang Biol 19(4):988-995

Cotrufo MF, Boot CM, Kampf S et al (2016) Redistribution of pyrogenic carbon from hillslopes to stream corridors following a large montane wildfire. Glob Biogeochem Cycles 30(9):2016GB005467

Czimczik CI, Masiello CA (2007) Controls on black carbon storage in soils. Glob Biogeochem Cycles 21(3):GB3005

D'Amore DV, Oken KL, Herendeen PA et al (2015) Carbon accretion in unthinned and thinned young-growth forest stands of the Alaskan perhumid coastal temperate rainforest. Carbon Balance Manag 10(1):25

Danso SKA, Bowen GD, Sanginga N (1992) Biological nitrogen fixation in trees in agro-ecosystems. Plant Soil 141(1-2):177-196

DeBano LF, Dunn PH, Conrad CE (1977) Fire's effect on physical and chemical properties of chaparral soils. Research Paper PSW-RP-145. U.S. Department of Agriculture, Forest Service, Pacific Southwest Forest and Range Experiment Station, Berkeley, $21 \mathrm{p}$

DeLuca TH, Aplet GH (2008) Charcoal and carbon storage in forest soils of the Rocky Mountain west. Front Ecol Environ 6:18-24

Dieleman WIJ, Vicca S, Dijkstra FA et al (2012) Simple additive effects are rare: a quantitative review of plant biomass and soil process responses to combined manipulations of $\mathrm{CO}_{2}$ and temperature. Glob Chang Biol 18(9):2681-2693

Doetterl S, Berhe AA, Nadeu E et al (2016) Erosion, deposition and soil carbon: a review of process-level controls, experimental tools and models to address $\mathrm{C}$ cycling in dynamic landscapes. Earth Sci Rev 154:102-122
Domke GM, Perry CH, Walters BF et al (2016) Estimating litter carbon stocks on forest land in the United States. Sci Total Environ 557-558:469-478

Domke GM, Perry CH, Walters BF et al (2017) Toward inventory-based estimates of soil organic carbon in forests of the United States. Ecol Appl 27:1223-1235

Dymond P, Scheu S, Parkinson D (1997) Density and distribution of Dendrobaena octaedra (Lumbricidae) in aspen and pine forests in the Canadian Rocky Mountains (Alberta). Soil Biol Biochem 29(3-4):265-273

Edburg SL, Hicke JA, Brooks PD et al (2012) Cascading impacts of bark beetle-caused tree mortality on coupled biogeophysical and biogeochemical processes. Front Ecol Environ 10(8):416-424

Ehrenfeld JG (2003) Effects of exotic plant invasions on soil nutrient cycling processes. Ecosystems 6(6):503-523

Ehrenfeld JG, Kourtev P, Huang W (2001) Changes in soil functions following invasions of exotic understory plants in deciduous forests. Ecol Appl 11(5):1287-1300

Esquilín AEJ, Stromberger ME, Massman WJ et al (2007) Microbial community structure and activity in a Colorado Rocky Mountain forest soil scarred by slash pile burning. Soil Biol Biochem 39:1111-1120

Federer CA (1993) The organic fraction-bulk density relationship and the expression of nutrient content in forest soils. Can J For Res 23:1026-1032

Forrester DI, Pares A, O'Hara C et al (2013) Soil organic carbon is increased in mixed-species plantations of Eucalyptus and nitrogenfixing Acacia. Ecosystems 16(1):123-132

Frandsen W, Ryan K (1986) Soil moisture reduces belowground heat flux and soil temperatures under a burning fuel pile. Can J For Res 16:244-248

Frank DA, Groffman PM (1998) Ungulate vs. landscape control of soil $\mathrm{C}$ and $\mathrm{N}$ processes in grasslands of Yellowstone National Park. Ecology 79(7):2229-2241

Frey SD, Ollinger S, Nadelhoffer K et al (2014) Chronic nitrogen additions suppress decomposition and sequester soil carbon in temperate forests. Biogeochemistry 121(2):305-316

Fuhlendorf SD, Engle DM (2001) Restoring heterogeneity on rangelands: ecosystem management based on evolutionary grazing patterns. Bioscience 51(8):625-632

Genet H, He Y, Lyu Z et al (2018) The role of driving factors in historical and projected carbon dynamics of upland ecosystems in Alaska. Ecol Appl 28(1):5-27

Giardina CP, Litton CM, Crow SE, Asner GP (2014) Warming-related increases in soil $\mathrm{CO}_{2}$ efflux are explained by increased belowground carbon flux. Nat Clim Chang 4:822-827

Gomez C, Rossel RAV, McBratney AB (2008) Soil organic carbon prediction by hyperspectral remote sensing and field Vis-NIR spectroscopy: an Australian case study. Geoderma 146(3-4):403-411

Gonzalez P, Asner GP, Battles JJ et al (2010) Forest carbon densities and uncertainties from Lidar, QuickBird, and field measurements in California. Remote Sens Environ 114(7):1561-1575

González-Pérez JA, González-Vila FJ, Almendros G, Knicker H (2004) The effect of fire on soil organic matter-a review. Environ Int 30(6):855-870

Grandy AS, Neff JC, Weintraub MN (2007) Carbon structure and enzyme activities in alpine and forest ecosystems. Soil Biol Biochem 39(11):2701-2711

Groffman PM, Bohlen PJ (1999) Soil and sediment biodiversity: cross-system comparisons and large-scale effects. Bioscience 49(2): 139-148

Hanan EJ, Schimel JP, Dowdy K, D'Antonio CM (2016) Effects of substrate supply, $\mathrm{pH}$, and char on net nitrogen mineralization and nitrification along a wildfire-structured age gradient in chaparral. Soil Biol Biochem 95:87-99 
Harmon ME, Ferrell WK, Franklin JF (1990) Effects of carbon storage on conversion of old-growth forests to young forests. Science 247:699-702

Harmon ME, Sexton J, Caldwell BA, Carpenter SE (1994) Fungal sporocarp mediated losses of $\mathrm{Ca}, \mathrm{Fe}, \mathrm{K}, \mathrm{Mg}, \mathrm{Mn}, \mathrm{N}, \mathrm{P}$, and $\mathrm{Zn}$ from conifer logs in the early stages of decomposition. Can J For Res 24(9): 1883-1893

Harrison K, Broecker W, Bonani G (1993) A strategy for estimating the impact of $\mathrm{CO}_{2}$ fertilization on soil carbon storage. Glob Biogeochem Cycles 7(1):69-80

Harrison RB, Footen PW, Strahm BD (2011) Deep soil horizons: contribution and importance to soil carbon pools and in assessing whole-ecosystem response to management and global change. For Sci 57(1):67-76

Harvey AE, Larsen MJ, Jurgensen MF (1976) Distribution of ectomycorrhizae in a mature Douglas-fir/larch forest soil in western Montana. For Sci 22(4):393-398

Harvey AE, Larsen MJ, Jurgensen MF (1981) Rate of woody residue incorporation into northern Rocky Mountain forest soils. Research Paper INT-RP-282. U.S. Department of Agriculture, Forest Service, Intermountain Forest and Range Experiment Station, Ogden, 5 p

Henry HA, Cleland EE, Field CB, Vitousek PM (2005) Interactive effects of elevated $\mathrm{CO}_{2}, \mathrm{~N}$ deposition and climate change on plant litter quality in a California annual grassland. Oecologia 142(3):465-473

Hickler T, Smith B, Prentice IC et al (2008) $\mathrm{CO}_{2}$ fertilization in temperate FACE experiments not representative of boreal and tropical forests. Glob Chang Biol 14(7):1531-1542

Hobbs RJ, Huenneke LF (1992) Disturbance, diversity, and invasion: implications for conservation. Conserv Biol 6(3):324-337

Holly DC, Ervin GN, Jackson CR et al (2009) Effect of an invasive grass on ambient rates of decomposition and microbial community structure: a search for causality. Biol Invasions 11(8):1855-1868

Homann PS, Bormann BT, Boyle JR (2001) Detecting treatment differences in soil carbon and nitrogen resulting from forest manipulations. Soil Sci Soc Am J 65(2):463-469

Hughes RF, Archer SR, Asner GP et al (2006) Changes in aboveground primary production and carbon and nitrogen pools accompanying woody plant encroachment in a temperate savanna. Glob Chang Biol 12(9):1733-1747

Hulme PE, Bacher S, Kenis M et al (2008) Grasping at the routes of biological invasions: a framework for integrating pathways into policy. J Appl Ecol 45(2):403-414

Humphreys ER, Black TA, Morgenstern K et al (2006) Carbon dioxide fluxes in coastal Douglas-fir stands at different stages of development after clearcut harvesting. Agric For Meteorol 140:6-22

Hungate BA, Holland EA, Jackson RB et al (1997) The fate of carbon in grasslands under carbon dioxide enrichment. Nature 388(6642):576-579

Intergovernmental Panel on Climate Change [IPCC] (2014) Climate Change 2014: synthesis report. Contribution of Working Groups I, II and III to the Fifth Assessment Report of the Intergovernmental Panel on Climate Change (Core Writing Team, Pachauri RK, Meyer LA (eds)). Geneva, Switzerland, $151 \mathrm{p}$

International Soil Carbon Network (n.d.) Homepage https://iscn.fluxdata.org. Accessed March 27, 2019

Jackson RB, Lajtha K, Crow SE et al (2017) The ecology of soil carbon: pools, vulnerabilities, and biotic and abiotic controls. Annu Rev Ecol Evol Syst 48(1):419-445

James J, Harrison R (2016) The effect of harvest on forest soil carbon: a meta-analysis. Forests 7(12):308

Jandl R, Lindner M, Vesterdal L et al (2007) How strongly can forest management influence soil carbon sequestration? Geoderma 137(3):253-268
Jang W, Keyes CR, Page-Dumroese DS (2015) Long-term effects on distribution of forest biomass following different harvesting levels in the northern Rocky Mountains. For Ecol Manag 358:281-290

Jang W, Page-Dumroese DS, Keyes CR (2016) Long-term changes from forest harvesting and residue management in the northern Rocky Mountains. Soil Sci Soc Am J 80(3):727-741

Janowiak MK, Webster CR (2010) Promoting ecological sustainability in woody biomass harvesting. J For 108(1):16-23

Janssens IA, Dieleman W, Luyssaert S et al (2010) Reduction of forest soil respiration in response to nitrogen deposition. Nat Geosci 3(5):315-322

Jenny H (1941) Factors of soil formation: a system of quantitative pedology. McGraw-Hill, New York, $281 \mathrm{p}$

Jo I, Potter KM, Domke GM, Fei S (2018) Dominant forest tree mycorrhizal type mediates understory plant invasions. Ecol Lett 21:217-224

Johansson MB (1994) The influence of soil scarification on the turnover rate of slash needles and nutrient release. Scand J For Res 9(1-4):170-179

Johnson DW, Curtis PS (2001) Effects of forest management on soil C and N storage: meta analysis. For Ecol Manag 140(2-3):227-238

Jurgensen MF, Larsen MJ, Graham RT, Harvey AE (1987) Nitrogen fixation in woody residue of northern Rocky Mountain conifer forests. Can J For Res 17(10):1283-1288

Jurgensen MF, Page-Dumroese DS, Brown RE et al (2017) Estimating carbon and nitrogen pools in a forest soil: influence of soil bulk density methods and rock content. Soil Sci Soc Am J 81:1689-1696

Kanakidou M, Myriokefalitakis S, Daskalakis N et al (2016) Past, present, and future atmospheric nitrogen deposition. J Atmos Sci 73:2039-2047

Kaňa J, Tahovská K, Kopáček J, Šantrůčková H (2015) Excess of organic carbon in mountain spruce forest soils after bark beetle outbreak altered microbial $\mathrm{N}$ transformations and mitigated N-saturation. PLoS One 10(7):e0134165

Kelleher BP, Simpson MJ, Simpson AJ (2006) Assessing the fate and transformation of plant residues in the terrestrial environment using HR-MAS NMR spectroscopy. Geochim Cosmochim Acta 70(16):4080-4094

Kleber M, Johnson MG (2010) Advances in understanding the molecular structure of soil organic matter: implications for interactions in the environment. Adv Agron 106:77-142

Klumpp K, Fontaine S, Attard E et al (2009) Grazing triggers soil carbon loss by altering plant roots and their control on soil microbial community. J Ecol 97(5):876-885

Knelman JE, Graham EB, Ferrenberg S et al (2017) Rapid shifts in soil nutrients and decomposition enzyme activity in early succession following forest fire. Forests 8(9):347

Kolka R, Sturtevant B, Townsend P et al (2014) Post-fire comparisons of forest floor and soil carbon, nitrogen, and mercury pools with fire severity indices. Soil Sci Soc Am J 78:S58-S65

Korb JE, Johnson NC, Covington WW (2004) Slash pile burning effects on soil biotic and chemical properties and plant establishment: recommendations for amelioration. Restor Ecol 12(1):52-62

Krebs J, Pontius J, Schaberg PG (2017) Modeling the impacts of hemlock woolly adelgid infestation and presalvage harvesting on carbon stocks in northern hemlock forests. Can J For Res 47:727-734

Kretchun AC, Scheller RM, Lucash MS et al (2014) Predicted effects of gypsy moth defoliation and climate change on forest carbon dynamics in the New Jersey Pine Barrens. PLoS One 9(8):e102531

Krofcheck DJ, Hurteau MD, Scheller RM, Loudermilk EL (2017) Prioritizing forest fuels treatments based on the probability of high-severity fire restores adaptive capacity in Sierran forests. Glob Chang Biol 24(2):729-737

Kurth VJ, Hart SC, Ross CS et al (2014) Stand-replacing wildfires increase nitrification for decades in southwestern ponderosa pine forests. Oecologia 175:395-407 
Ladwig LM, Sinsabaugh RL, Collins SL, Thomey ML (2015) Soil enzyme responses to varying rainfall regimes in Chihuahuan Desert soils. Ecosphere 6(3):1-10

Langmaid KK (1964) Some effects of earthworm invasion in virgin podzols. Can J Soil Sci 44(1):34-37

Laycock WA (1991) Stable states and thresholds of range condition on North American rangelands: a viewpoint. J Range Manag 44(5):427-433

Lehmann J, Kleber M (2015) The contentious nature of soil organic matter. Nature 528(7580):60-68

Leslie J (2017) Soil power! The dirty way to a green planet The New York Times, Opinion. December 2. https://www.nytimes. com/2017/12/02/opinion/sunday/soil-power-the-dirty-way-to-agreen-planet.html. Accessed June 21, 2018)

Liang B, Lehmann J, Solomon D et al (2006) Black carbon increases cation exchange capacity in soils. Soil Sci Soc Am J 70:1719-1730

Liu S, Liu J, Young CJ et al (2012) Chapter 5: Baseline carbon storage, carbon sequestration, and greenhouse-gas fluxes in terrestrial ecosystems of the western United States. In: Zhu Z, Reed BC (eds) Baseline and projected future carbon storage and greenhouse-gas fluxes in ecosystems of the western United States. Professional paper 1797. U.S. Department of the Interior, Geological Survey, Reston. Available at https://pubs.usgs.gov/pp/1797. Accessed March 21, 2019

Liu S, Wei Y, Post WM et al (2013) The Unified North American Soil Map and its implication on the soil organic carbon stock in North America. Biogeosciences 10:2915

Liu S, Liu J, Wu Y et al (2014) Chapter 7: Baseline and projected future carbon storage, carbon sequestration, and greenhouse-gas fluxes in terrestrial ecosystems of the eastern United States. In: Zhu Z, Reed BC (eds) Baseline and projected future carbon storage and greenhouse gas fluxes in ecosystems of the eastern United States, Professional paper 1804. U.S. Department of the Interior, Geological Survey, Reston, pp 115-156. Available at https://pubs. usgs.gov/pp/1804. Accessed March 21, 201

Liu S, Zhang Y, Zong Y et al (2016) Response of soil carbon dioxide fluxes, soil organic carbon and microbial biomass carbon to biochar amendment: a meta-analysis. GCB Bioenergy 8(2):392-406

Lu M, Zhou X, Yang Q et al (2013) Responses of ecosystem carbon cycle to experimental warming: a meta-analysis. Ecology 94(3):726-738

Lybrand RA, Heckman K, Rasmussen C (2017) Soil organic carbon partitioning and $\Delta{ }^{14} \mathrm{C}$ variation in desert and conifer ecosystems of southern Arizona. Biogeochemistry 134(3):261-277

Lynch LM, Machmuller MB, Cotrufo MF et al (2018) Tracking the fate of fresh carbon in the Arctic tundra: will shrub expansion alter responses of soil organic matter to warming? Soil Biol Biochem 120:134-144

Mack MC, D'Antonio CM, Ley RE (2001) Alteration of ecosystem nitrogen dynamics by exotic plants: a case study of $\mathrm{C} 4$ grasses in Hawaii. Ecol Appl 11(5):1323-1335

MacKenzie MD, DeLuca TH, Sala A (2004) Forest structure and organic horizon analysis along a fire chronosequence in the low elevation forests of western Montana. For Ecol Manag 203:331-343

Markewitz D (2006) Fossil fuel carbon emissions from silviculture: impacts on net carbon sequestration in forests. For Ecol Manag 236:153-161

Marschner B, Brodowski S, Dreves A et al (2008) How relevant is recalcitrance for the stabilization of organic matter in soils? J Plant Nutr Soil Sci 171(1):91-110

Maser C, Cline SP, Cromack K Jr et al (1988) What we know about large trees that fall to the forest floor. In: Maser C, Tarrant RF, Trappe JM, Franklin JF (eds) From the forest to the sea: a story of fallen trees. General Technical Report PNW-GTR-229. U.S. Department of Agriculture, Forest Service, Pacific Northwest Research Station; Portland, pp 25-46
Massman WJ, Frank JM (2005) Effect of a controlled burn on the thermophysical properties of a dry soil using a new model of soil heat flow and a new high temperature heat flux sensor. Int J Wildland Fire 13(4):427-442

Matthes JH, Lang AK, Jevon FV, Russell SJ (2018) Tree stress and mortality from emerald ash borer does not systematically alter shortterm soil carbon flux in a mixed northeastern U.S. forest. Forests 9:37

Maurer GE, Chan AM, Trahan NA et al (2016) Carbon isotopic composition of forest soil respiration in the decade following bark beetle and stem girdling disturbances in the Rocky Mountains. Plant Cell Environ 39:1513-1523

McSherry ME, Ritchie ME (2013) Effects of grazing on grassland soil carbon: a global review. Glob Chang Biol 19(5):1347-1357

Millennium Ecosystem Assessment (2003) Ecosystem and human wellbeing: a framework for assessment. Island Press, Washington, DC

Minasny B, Malone BP, McBratney AB et al (2017) Soil carbon 4 per mille. Geoderma 292:59-86

Morehouse K, Johns T, Kaye J, Kaye M (2008) Carbon and nitrogen cycling immediately following bark beetle outbreaks in southwestern ponderosa pine forests. For Ecol Manag 255:2698-2708

Nagel LM, Palik BJ, Battaglia MA et al (2017) Adaptive silviculture for climate change: a national experiment in manager-scientist partnerships to apply an adaptation framework. J For 115(3):167-178

National Forest Management Act of 1976; Act of October 22, 1976; 16 U.S.C. 1600

Nave LE, Vance ED, Swanston CW, Curtis PS (2010) Harvest impacts on soil carbon storage in temperate forests. For Ecol Manag 259:857-866

Nave LE, Domke GM, Hofmeister KL et al (2018) Reforestation can sequester two petagrams of carbon in U.S. topsoils in a century. Proc Natl Acad Sci 115(11):2776-2781

Neary DG, Klopatek CC, DeBano LF, Ffolliott PF (1999) Fire effects on belowground sustainability: a review and synthesis. For Ecol Manag 122:51-71

Neary DG, Trettin CC, Page-Dumroese D (2010) Soil quality monitoring: examples of existing protocols. In: Page-Dumroese D, Neary D, Trettin C (eds) Scientific background for soil monitoring on national forests and rangelands: workshop proceedings. Proceedings RMRS-P-59. U.S. Department of Agriculture, Forest Service, Rocky Mountain Research Station, Fort Collins, pp 61-77

Neff JC, Reynolds RL, Belnap J, Lamothe P (2005) Multi-decadal impacts of grazing on soil physical and biogeochemical properties in southeast Utah. Ecol Appl 15(1):87-95

Neff JC, Barger NN, Baisden WT et al (2009) Soil carbon storage responses to expanding pinyon-juniper populations in southern Utah. Ecol Appl 19:1405-1416

Norton JB, Monaco TA, Norton U (2007) Mediterranean annual grasses in western North America: kids in a candy store. Plant Soil 298(1-2):1-5

Noss RF (2001) Beyond Kyoto: forest management in a time of rapid climate change. Conserv Biol 15(3):578-590

Nuzzo VA, Maerz JC, Blossey B (2009) Earthworm invasion as the driving force behind plant invasion and community change in northeastern North American forests. Conserv Biol 23(4):966-974

O'Neill KP, Amacher MC, Perry CH (2005) Soils as an indicator of forest health: a guide to the collection, analysis, and interpretation of soil indicator data in the Forest Inventory and Analysis program. General Technical Report NC-GTR-258. U.S. Department of Agriculture, Forest Service, North Central Research Station, St. Paul, $53 \mathrm{p}$

Oldfield EE, Wood SA, Bradford MA (2017) Direct effects of soil organic matter on productivity mirror those observed with organic amendments. Plant Soil 423(1-2):363-373 
Ouimet R, Tremblay S, Périé C, Prégent G (2007) Ecosystem carbon accumulation following fallow farmland afforestation with red pine in southern Québec. Can J For Res 37(6):1118-1133

Owen JJ, Parton WJ, Silver WL (2015) Long-term impacts of manure amendments on carbon and greenhouse gas dynamics of rangelands. Glob Chang Biol 21(12):4533-4547

Page-Dumroese DS, Jurgensen MF (2006) Soil carbon and nitrogen pools in mid- to late-successional forest stands of the northwestern United States: potential impact of fire. Can J For Res 36:2270-2284

Page-Dumroese DS, Brown RE, Jurgensen MF, Mroz GD (1999) Comparison of methods for determining bulk densities of rocky forest soils. Soil Sci Soc Am J 63(2):379-383

Page-Dumroese DS, Coleman MD, Thomas SC (2017) Chapter 15: Opportunities and uses of biochar on forest sites in North America. In: Bruckman V, Varol A, Uzun BB, Liu J (eds) Biochar: a regional supply chain approach in view of mitigating climate change. Cambridge University Press, Cambridge, UK, pp 315-336

Page-Dumroese DS, Ott MR, Strawn DG, Tirocke JM (2018) Using organic amendments to restore soil physical and chemical properties of a mine site in northeastern Oregon, USA. Appl Eng Agric 34(1):43-55

Pan Y, Birdsey RA, Fang J et al (2011) A large and persistent carbon sink in the world's forests. Science 333(6045):988-993

Pellegrini AFA, Ahlström A, Hobbie SE et al (2017) Fire frequency drives decadal changes in soil carbon and nitrogen and ecosystem productivity. Nature 553:194-198

Peltzer DA, Allen RB, Lovett GM et al (2010) Effects of biological invasions on forest carbon sequestration. Glob Chang Biol 16(2):732-746

Phillips RP, Meier IC, Bernhardt ES et al (2012) Roots and fungi accelerate carbon and nitrogen cycling in forests exposed to elevated $\mathrm{CO}_{2}$. Ecol Lett 15(9):1042-1049

Piene H, Van Cleve K (1978) Weight loss of litter and cellulose bags in a thinned white spruce forest in interior Alaska. Can J For Res $8(1): 42-46$

Piñeiro G, Paruelo JM, Oesterheld M, Jobbágy EG (2010) Pathways of grazing effects on soil organic carbon and nitrogen. Rangel Ecol Manag 63(1):109-119

Post WM, Kwon KC (2000) Soil carbon sequestration and land-use change: processes and potential. Glob Chang Biol 6(3):317-327

Powers RF, Scott DA, Sanchez FG (2005) The North American longterm soil productivity experiment: findings from the first decade of research. For Ecol Manag 220(1):31-50

Prater MR, Obrist D, Arnone JA III, DeLucia EH (2006) Net carbon exchange and evapotranspiration in postfire and intact sagebrush communities in the Great Basin. Oecologia 146(4):595-607

Prieto-Fernández A, Acea MJ, Carballas T (1998) Soil microbial and extractable C and N after wildfire. Biol Fertil Soils 27(2):132-142

Raison RJ (1979) Modification of the soil environment by vegetation fires, with particular reference to nitrogen transformations: a review. Plant Soil 51:73-108

Reddy AD, Hawbaker TJ, Wurster F et al (2015) Quantifying soil carbon loss and uncertainty from a peatland wildfire using multitemporal LiDAR. Remote Sens Environ 170:306-316

Reeder JD, Schuman GE (2002) Influence of livestock grazing on C sequestration in semi-arid mixed-grass and short-grass rangelands. Environ Pollut 116(3):457-463

Reisser M, Purves RS, Schmidt MWI, Abiven S (2016) Pyrogenic carbon in soils: a literature-based inventory and a global estimation of its content in soil organic carbon and stocks. Front Earth Sci 4:80

Rhoades CC, Hubbard RM, Elder K (2017) A decade of streamwater nitrogen and forest dynamics after a mountain pine beetle outbreak at the Fraser experimental Forest, Colorado. Ecosystems 20(2):380-392
Robichaud PR, Lewis SA, Wagenbrenner JW et al (2013) Post-fire mulching for runoff and erosion mitigation: part I: effectiveness at reducing hillslope erosion rates. Catena 105:75-92

Russell WH, McBride JR (2003) Landscape scale vegetation-type conversion and fire hazard in the San Francisco bay area open spaces. Landsc Urban Plan 64(4):201-208

Sackett SS, Haase SM (1992) Measuring soil and tree temperatures during prescribed fires with thermocouple probes. General Technical Report PSW-GTR-131. U.S. Department of Agriculture, Forest Service, Pacific Southwest Research Station, Berkeley, $15 \mathrm{p}$

Sánchez Meador A, Springer JD, Huffman DW et al (2017) Soil functional responses to ecological restoration treatments in frequent-fire forests of the western United States: a systematic review. Restor Ecol 25(4):497-508

Sanchez FG, Tiarks AE, Kranabetter JM et al (2006) Effects of organic matter removal and soil compaction on fifth-year mineral soil carbon and nitrogen contents for sites across the United States and Canada. Can J For Res 36(3):565-576

Sanford RL Jr, Parton WJ, Ojima DS, Lodge DJ (1991) Hurricane effects on SOC dynamics and forest production in the Luquillo Experimental Forests, Puerto Rico: results of simulation modeling. Biotropica 24:364-372

Schaedel MS, Larson AJ, Affleck DLR et al (2017) Early forest thinning changes aboveground carbon distribution among pools, but not total amount. For Ecol Manag 389:187-198

Scharlemann JPW, Tanner EVJ, Hiederer R, Kapos V (2014) Global soil carbon: understanding and managing the largest terrestrial carbon pool. Carbon Manage 5:81-91

Scheu S, Parkinson D (1994) Effects of earthworms on nutrient dynamics, carbon turnover and microorganisms in soils from cool temperate forests of the Canadian Rocky Mountains-laboratory studies. Appl Soil Ecol 1(2):113-125

Schlesinger WH, Lichter J (2001) Limited carbon storage in soil and litter of experimental forest plots under increased atmospheric $\mathrm{CO}_{2}$. Nature 411(6836):466-469

Schmidt MWI, Torn MS, Abiven S et al (2011) Persistence of soil organic matter as an ecosystem property. Nature 478:49-56

Schnitzer M, Kodama H (1977) Reactions of minerals with soil humic substances. In: Dixon JB, Weed SB (eds) Minerals and their roles in the soil environment. Soil Science Society of America, Madison, pp 741-770

Schoenholtz SH, Miegroet HV, Burger JA (2000) A review of chemical and physical properties as indicators of forest soil quality: challenges and opportunities. For Ecol Manag 138(1):335-356

Schreiner EG, Krueger KA, Houston DB, Happe PJ (1996) Understory patch dynamics and ungulate herbivory in old-growth forests of Olympic National Park, Washington. Can J For Res 26(2):255-265

Schuman GE, Janzen HH, Herrick JE (2002) Soil carbon dynamics and potential carbon sequestration by rangelands. Environ Pollut 116(3):391-396

Schuur EAG, McGuire AD, Schädel C et al (2015) Climate change and the permafrost carbon feedback. Nature 520(7546):171-179

Scott NA, Saggar S, McIntosh PD (2001) Biogeochemical impact of Hieracium invasion in New Zealand's grazed tussock grasslands: sustainability implications. Ecol Appl 11(5):1311-1322

Sierra CA, Trumbore SE, Davidson EA et al (2015) Sensitivity of decomposition rates of soil organic matter with respect to simultaneous changes in temperature and moisture. J Adv Model Earth Syst 7:335-356

Silver WL, Ryals R, Eviner V (2010) Soil carbon pools in California's annual grassland ecosystems. Rangel Ecol Manag 63(1):128-136

Spears JDH, Holub SM, Harmon ME, Lajtha K (2003) The influence of decomposing logs on soil biology and nutrient cycling in an oldgrowth mixed coniferous forest in Oregon, USA. Can J For Res 33(11):2193-2201 
Steinbeiss S, Gleixner G, Antonietti M (2009) Effect of biochar amendment on soil carbon balance and soil microbial activity. Soil Biol Biochem 41(6):1301-1310

Sulman BN, Phillips RP, Oishi AC et al (2014) Microbe-driven turnover offsets mineral-mediated storage of soil carbon under elevated $\mathrm{CO}_{2}$. Nat Clim Chang 4(12):1099-1102

Sundquist ET, Ackerman KV, Bliss NB et al (2009) Rapid assessment of U.S. forest and soil organic carbon storage and forest biomass carbon-sequestration capacity. Open-File Report 2009-1283. U.S. Department of the Interior, Geological Survey, Reston, 15 p. https://pubs.er.usgs.gov/publication/ofr20091283

Sutton R, Sposito G (2005) Molecular structure in soil humic substances: the new view. Environ Sci Technol 39(23):9009-9015

Svejcar T, Angell R, Bradford JA et al (2008) Carbon fluxes on North American rangelands. Rangel Ecol Manag 61:465-474

Tate RL III (1987) Soil organic matter: biological and ecological effects. Wiley Interscience, New York, 291 p

Thomey ML, Collins SL, Vargas R et al (2011) Effect of precipitation variability on net primary production and soil respiration in a Chihuahuan Desert grassland. Glob Chang Biol 17:1505-1515

Thornton PE, Law BE, Gholz HL et al (2002) Modeling and measuring the effects of disturbance history and climate on carbon and water budgets in evergreen needleleaf forests. Agric For Meteorol 113:185-222

Trahan NA, Dynes EL, Pugh E et al (2015) Changes in soil biogeochemistry following disturbance by girdling and mountain pine beetles in subalpine forests. Oecologia 177(4):981-995

U.S. Global Change Research Program [USGCRP] (2018) Second State of the Carbon Cycle Report (SOCCR2): a sustained assessment report (Cavallaro N, Shrestha G, Birdsey R et al (eds)). Washington, DC. $878 \mathrm{p}$
USDA Forest Service [USDA FS] (2012) National Forest System land management planning rule. 36 CFR part 219 RIN0596-AD2. Fed Regist Rules Regul 77(68):21162-21276

Van Miegroet H, Jandl R (2007) Are nitrogen-fertilized forest soils sinks or sources of carbon? Environ Monit Assess 128(1-3):121-131

Vesterdal L, Dalsgaard M, Felby C et al (1995) Effects of thinning and soil properties on accumulation of carbon, nitrogen and phosphorus in the forest floor of Norway spruce stands. For Ecol Manag 77(1-3):1-10

Wagai R, Mayer LM, Kitayama K, Knicker H (2008) Climate and parent material controls on organic matter storage in surface soils: a three-pool, density-separation approach. Geoderma 147(1-2):23-33

Wagai R, Mayer LM, Kitayama K (2009) Nature of the "occluded" low-density fraction in soil organic matter studies: a critical review. Soil Sci Plant Nutr 55(1):13-25

Warnock DD, Litvak ME, Morillas L, Sinsabaugh RL (2016) Droughtinduced piñon mortality alters the seasonal dynamics of microbial activity in piñon-juniper woodland. Soil Biol Biochem 92:91-101

Wolfe BE, Klironomos JN (2005) Breaking new ground: soil communities and exotic plant invasion. Bioscience 55(6):477-487

Yanai RD, Arthur MA, Siccama TG, Federer CA (2000) Challenges of measuring forest floor organic matter dynamics. For Ecol Manag 138(90):273-283

Zhang Y, Wolfe SA, Morse PD et al (2015a) Spatiotemporal impacts of wildfire and climate warming on permafrost across a subarctic region, Canada: impacts of fire on permafrost. J Geophys Res Earth 120(11):2338-2356

Zhang B, Zhou X, Zhou L, Ju R (2015b) A global synthesis of belowground carbon responses to biotic disturbance: a meta-analysis. Glob Ecol Biogeogr 24(2):126-138

Open Access This chapter is licensed under the terms of the Creative Commons Attribution 4.0 International License (http://creativecommons. org/licenses/by/4.0/), which permits use, sharing, adaptation, distribution and reproduction in any medium or format, as long as you give appropriate credit to the original author(s) and the source, provide a link to the Creative Commons license and indicate if changes were made.

The images or other third party material in this chapter are included in the chapter's Creative Commons license, unless indicated otherwise in a credit line to the material. If material is not included in the chapter's Creative Commons license and your intended use is not permitted by statutory regulation or exceeds the permitted use, you will need to obtain permission directly from the copyright holder. 